\title{
Objeto contractual y transferencia de propiedad
}

\author{
Marco Antonio Ortega Piana
}

En el presente artículo, el Profesor

Marco Antonio Ortega realiza un agudo análisis acerca de la intención del legislador al momento de regular el objeto contractual en el Código Civil de 1984. Analiza, también, las opiniones de los más destacados juristas, nacionales e internacionales, del área del derecho civil respecto al tema. Finalmente, concluye su artículo exponiendo una clara posición acerca de la relación entre el objeto contractual y la transferencia convencional de la propiedad inmueble, según las normas de nuestro Código Civil.

Abogado por la Pontificia Universidad Católica del Perú. Profesor de derecho civil patrimonial en la Universidad de Lima y en la Universidad ESAN. Consejero del Estudio Grau abogados. 


\section{Introducción}

El presente trabajo está orientado a dejar constancia de una determinada posición con relación al objeto contractual conforme al Código Civil peruano. Corresponde al propósito de evidenciar qué es lo que se habría representado el legislador en el proceso de codificación que concluyó en 1984. En las aulas y en el ejercicio profesional muchas veces adoptamos como propias lo que son simplemente interpretaciones ajenas sin compulsarlas con ciertos antecedentes; por ello, este trabajo reclama finalmente que el lector asuma una posición sobre el tema. Toda discrepancia será bienvenida, porque generará finalmente un punto de encuentro en el camino para alcanzar un conocimiento más informado.

Conforme a ello, se postula que, según el diseño legislativo nacional, los contratos no sólo tienen como objeto a las obligaciones -como relaciones jurídicas patrimoniales específicas- sino que, en función de ello, no es posible sostener que en materia de transferencia convencional de propiedad nos encontremos ante un sistema mixto o dual conforme al cual, tratándose de la transmisión de propiedad inmobiliaria nos sujetamos a un régimen con efectos traslativos mientras que, tratándose de la transmisión mobiliaria, ante un régimen con efectos crediticios.

Entendemos que, sobre la base del artículo 1402 del Código Civil, que representa una norma fundamental en el campo de la contratación privada, y que se asocia a otras tantas que conforman una unidad sistemática sólida y coherente, debe concluirse que todo contrato es obligacional y que, de manera correlativa, en materia de transferencia convencional de propiedad, nos adscribimos a la denominada teoría del título y modo, por lo que en función a ello deben ser leídos y aplicados los artículos 947 y 949 del Código Civil.

Cuestión distinta es el juicio que cada quien está llamado a realizar sobre si la regulación legislativa relativa al objeto contractual es la más idónea para fines del tráfico jurídico, si genera o no la necesaria seguridad, dado que como toda opción legislativa es susceptible de crítica y perfeccionamiento. Pero esa evaluación debe partir de algo cierto, identificar qué es lo que se representó el codificador nacional al regular de una determinada manera al objeto contractual, atendiendo a que tuvo ante sí diversos modelos legislativos. Podremos sostener que no ha habido estrictamente un legislador, sino legisladores, y que estos últimos se han sucedido en el tiempo, porque una cosa es el diseño legislativo bajo la denominada "Comisión Reformadora"1

La denominada "Comisión Reformadora" fue creada mediante Decreto Supremo 95 del 1 de marzo de 1965 expedido durante el primer gobierno constitucional del presidente Fernando Belaúnde. A los miembros de dicha comisión se les encargó el estudio y revisión del Código Civil de 1936, esto es, cuando el mismo no había cumplido ni siquiera treinta años de vigencia. Entre sus miembros más renombrados tenemos, en un primer momento, a Carlos Fernández Sessarego, José León Barandiarán, Rómulo Lanatta Güilhem, Héctor Cornejo Chávez y Max Arias-Schreiber Pezet, siendo que de manera 
y otra bajo la "Comisión Revisora", pero en cualquier caso no debemos asumir que el sentido de la legislación es necesariamente aquello que postulamos hoy en día, muchas veces más influenciados por lecturas foráneas que considerando las razones por las que el Código Civil contiene ciertas reglas, y no otras como se quisiera.

Atendiendo a lo expuesto, carece de adecuado fundamento proponer interpretaciones sustentadas en una mera literalidad, o tomar como concluyente lo que puede ser válido bajo otras legislaciones, por más que hubiesen inspirado de alguna manera a los textos nacionales. Como todo en la vida, hay que regresar a los orígenes para dimensionar adecuadamente el sentido de lo actual, y bajo esa comprensión proyectarnos al futuro.

En ese contexto adquieren más vigencia que nunca las palabras del maestro De la Puente $^{3}$, contenidas significativamente en la parte final de su magna obra "El contrato en general", cuando nos expresa:

"No quiero terminar esta obra sin expresar una preocupación que me desasosiega. Pese a considerar que la Sección Primera del Libro VII del Código civil constituye un excelente conjunto de disposiciones que de manera coherente profundiza con responsabilidad la problemática de la contratación moderna, debo reconocer que como toda factura humana, adolece de defectos que afean la obra legislativa. Frente a estos incuestionables defectos, existe una corriente de opinión que, no obstante su loable mérito en destacarlos, se orienta a corregirlos mediante la modificación o supresión de las normas jurídicas correspondientes. Pienso que debemos afrontar una realidad. Los Códigos no son una secuencia de disposiciones colocadas caprichosamente unas al lado de las otras, sino un todo orgánico en que cada una de sus normas, especialmente las que integran cada Sección, responde a un plan integral que las vincula íntima y

posterior se integran Felipe Osterling Parodi, Jorge Avendaño Valdez, Lucrecia Maisch Von Humboldt, Manuel de la Puente y Lavalle y Fernando de Trazegnies Granda, entre otros renombrados juristas. Si bien el encargo inicial fue proponer las modificaciones necesarias al Código Civil de 1936, sus miembros optaron finalmente por elaborar y proponer un texto sustitutorio, un nuevo código civil. Los trabajos de esta comisión se extenderán hasta 1981, cuando se presenta al Poder Ejecutivo (segundo gobierno constitucional del presidente Fernando Belaúnde) el respectivo proyecto (1981).

2 La "Comisión Revisora" fue creada por Ley Nro. 23403, promulgada en mayo de 1982, y tenía precisamente por objeto revisar el denominado primer proyecto o proyecto elaborado por la "Comisión Reformadora". Entre sus miembros más destacados figuraban Javier Alva Orlandini, Roberto Ramírez del Villar, César Fernández Arce y Jack Bigio Chrem. Su competencia fue complementada mediante Ley 23756, promulgada en diciembre de 1983. Los trabajos de esta comisión se extenderán hasta julio de 1984, cuando se presenta al Poder Ejecutivo el respectivo proyecto (el que bien puede ser llamado segundo proyecto, elaborado sobre la base del primer proyecto).

3 De la Puente y Lavalle, Manuel, El contrato en general. Comentarios a la Sección Primera del Libro VII del Código Civil, Tomo III, Palestra Editores, Lima, 2011, pp. 667-668. 
ordenadamente, de tal manera que el cambio o supresión de una de ellas rompe la armonía del conjunto. Como los Códigos no pueden sustituirse rápidamente, pues son redactados con una vocación de permanencia, pienso que el camino adecuado es tomar una actitud más positiva e intentar la interpretación de la norma cuestionada utilizando especialmente los medios o elementos lógico y sistemático, para otorgarle su verdadero sentido a través de su relación con las demás en su conjunto. Sólo así lograremos conservar nuestro Código de acuerdo a la concepción que lo inspiró, adecuando meditadamente su espíritu a la constante evolución del Derecho, sin restarle coherencia y unidad. Es admirable, en este sentido, la jurisprudencia francesa que ha logrado actualizar el viejo Código Napoleón, sin necesidad de recurrir a cambios legislativos superables.

Únicamente si se detectan verdaderos errores conceptuales innatos, que resulten insalvables de otro modo, será menester tomar el duro camino de la modificación radical. De igual manera, esa medida deberá tomarse si el devenir nos depara tales cambios ideológicos en la noción del Derecho contractual que la reestructuración de su manifestación positiva sea inevitable para adecuarse a la nueva realidad".

Por último, ingresando al plano personal, dejamos constancia de un especial agradecimiento a la revista FORSETI, publicada por los alumnos de Derecho de la Universidad del Pacífico, por la oportunidad brindada para compartir las reflexiones contenidas en el presente trabajo, felicitando a sus miembros por esa encomiable vocación de convertirse en la mejor fuente de consulta jurídica, vocación que nos obliga diariamente a la búsqueda de la excelencia.

\section{Sobre el objeto contractual}

1. Para comenzar debemos precisar qué es lo que entendemos por objeto contractual. De las diversas acepciones de las que nos informa nuestro idioma ${ }^{4}$, tenemos dos que pueden resultar pertinentes para este trabajo. De un lado, objeto es el fin o propósito a que se dirige o encamina una acción u operación. De otro lado, objeto es simplemente una cosa, un bien material.

Es relevante traer a colación el significado del término conforme al DRAE porque no podemos olvidar que los lenguajes comunes, académicos y legislativos no son necesariamente coincidentes ${ }^{5}$.

El lenguaje común es simplemente el cotidiano, comprensible para las mayorías, para todos los miembros de una colectividad. El lenguaje académico corresponde a una

$4 \quad$ Nos remitimos al enlace web de la Real Academia Española, que corresponde al Diccionario de la Real Academia Española (DRAE). En línea: http://lema.rae.es/drae

5 Alterini, Jorge H., Corna, Pablo M., Angelani, Elsa B., y Vásquez, Gabriela A., Teoría General de las Ineficacias, La Ley S.A., Buenos Aires, 2000, pp. 1-7. 
aspiración de mayor precisión, es técnico para los fines de la ciencia jurídica, en consecuencia, no es comprensible necesariamente para todos. $Y$ el lenguaje legislativo tiene alcances especiales, debe ser comprensible en general, pero tampoco debe alejarse de la rigurosidad jurídica.

El problema es que muchas veces lo legislativo lo leemos como si fuese un lenguaje académico, y no es así definitivamente; el lenguaje legislativo debería estar más identificado con el cotidiano, salvo en aquellos aspectos en que resulte indispensable la precisión académica. Por ello, creemos firmemente que el lenguaje legislativo debe ser sencillo y comprensible, ajeno a interpretaciones sutiles. El Código Civil no puede ser tomado ni apreciado como un tratado de derecho. Así, Montesquieu en su obra "El espíritu de las leyes" postulaba que:

"El estilo debe ser conciso (...) debe ser sencillo; la expresión directa se comprende mejor que la figurada (...) Es de esencia que las palabras de las leyes despierten en todos las misma ideas (...) Las leyes no deben ser sutiles, se hacen para gentes de mediano entendimiento; no son un arte de lógica, sino la simple razón de un padre de familia (...) Es menester procurar que las leyes no estén concebidas de manera que pugnen con la naturaleza de las cosas $(\ldots)^{\prime \prime}$.

Atendiendo a lo expresado, debe realizarse el esfuerzo de discernir a qué se ha referido el legislador nacional al regular el objeto contractual. Si bien uno puede sostener que el objeto contractual (fin) debe ser lícito, también podría señalarse que el objeto contractual (cosa) debe ser determinado o determinable, o existente o con posibilidad de existencia. Todos sabemos que los términos pueden ser polisémicos, como bien destaca Roppo ${ }^{7}$, de manera que en lo jurídico una misma palabra puede tener significados distintos, como ocurre tratándose de "dolo" en materia de acto jurídico, de inejecución de obligaciones voluntarias y de responsabilidad civil.

Lo que sostenemos es que, para fines del Código Civil, objeto contractual es sinónimo de aquello que las partes pretenden jurídicamente, identificándose con su propósito, con carácter abstracto, pero apreciándose también desde la perspectiva que hay de por medio un interés relevante o merecedor de tutela. Y sobre dicha base, el legislador ha sido consistente en enunciar el atributo o característica que debe revestir ese "objeto", diferenciándolo claramente de los atributos relativos al contenido de ese objeto. $Y$ ese entendimiento no fluye de uno o dos artículos entre cientos de cientos que conforman al Código Civil, sino que se aprecia de una lectura serena y sistemática

6 Citado por Alterini, Jorge H., Corna, Pablo M., Angelani, Elsa B., y Vásquez, Gabriela A., Teoría General de las Ineficacias, La Ley S.A., Buenos Aires, 2000, p. 6.

7 Roppo, Vincenzo. El Contrato, $1^{\text {a }}$ edición, trad. Ariano Deho, Eugenia, Gaceta Jurídica, Lima, 2009, pp. 43-44. 
de este último. Hay una determinada concepción jurídica que ha sido expresada en diversos libros del texto legal y en distintos artículos ${ }^{8}$.

2. A diferencia de otras regulaciones que omiten hacerlo y que se limitan a enunciar las características del objeto contractual, nuestro Código Civil contiene innovadoramente en nuestra tradición civilista, una definición de lo que es el objeto del contrato contenida en su artículo 1402-, la misma que por elemental criterio de especialidad prima sobre cualquier otra disposición que pudiese considerarse como pertinente.

El artículo 1402 del Código Civil establece que: "El objeto del contrato consiste en crear, regular, modificar o extinguir obligaciones".

Es así que, por declaración expresa, el objeto de todo contrato, es obligacional, esto es, el respectivo acuerdo de voluntades busca o pretende, tiene como propósito, crear, regular, modificar o extinguir obligaciones, las mismas que son una especie dentro del vasto género de las relaciones jurídico-patrimoniales.

Y conforme analizaremos, no estamos ante una simple definición, sino que la misma representa conscientemente una determinada toma de posición. No se trata, por consiguiente, de una simple definición que sigue a la tradición jurídica, como si esta última fuese invariable, fruto virtual de una suerte de revelación divina y que constituye fundamento del conocimiento jurídico, sino que estamos ante una determinada opción por la que se inclinó el legislador nacional ${ }^{9}$. Como veremos, el codificador de 1984 pudo omitir incorporar una definición, o pudo considerar una distinta (dado que, en palabras de Gabrielli ${ }^{10}$ se está ante una materia "muy debatida y controvertida"), pero acogió finalmente una bastante puntual y concreta, sobre la base de su concepción que el contrato pretende satisfacer finalmente un determinado interés.

8 Así, por ejemplo, los debates jurídicos en nuestro sistema legal sobre la naturaleza jurídica del contrato sobre hecho ajeno, o sobre el acuerdo de opción, se simplificarían tremendamente si partimos de un común entendimiento que el objeto del contrato sólo puede ser legalmente uno: relaciones obligacionales con todo lo que se desprende de ello, esto es, contenido prestacional, conducta posible en cabeza del deudor, quien es parte material de la respectiva relación contractual.

9 Legislar implica optar. Nos remitimos a un caso, entre tantos, en el ámbito contractual. En su momento, ante la posibilidad de regular que se trataba de un negocio anulable o rescindible, y según expresa el profesor Jack Bigio, el codificador se inclinó por esto último (rescindibilidad) tratándose de la venta de bien ajeno, siendo que el fundamento fue simplemente pragmático: en qué consiste la carga probatoria y cuál es el plazo para accionar, conforme se destaca nada menos que en la Exposición de Motivos Oficial del Código Civil (Comisión Revisora del Código Civil de acuerdo a las Leyes 24039 y 24136) El bien materia de la venta (artículos 1532 a 1542 del Código Civil), separata especial del Diario Oficial El Peruano publicada el 11 de febrero de 1991, p. 12.

10 Gabrielli, Enrico, Estudios sobre teoría general del contrato, trad. Morales Hervias, Rómulo y Vásquez Rebaza, Walter, Jurista Editores, Lima, 2013, p. 266. 
3. La cuestión radica en que se intenta oponer dicha regla, prácticamente silenciándola, respecto al artículo 1351 del Código Civil (que también representa una innovación del código vigente), el mismo que define, entre las disposiciones generales contenidas en la Sección Primera (Contratos en general) del Libro VII (Fuentes de las obligaciones) del referido cuerpo normativo, lo que es un contrato.

El artículo 1351 del Código Civil establece que: 'El contrato es el acuerdo de dos o más partes para crear, regular, modificar o extinguir una relación jurídica patrimonial".

No hay duda alguna que un contrato es un acuerdo de voluntades, que implica un consentimiento, un querer común, lo cual es admitido pacíficamente por la doctrina. Tampoco hay duda que un contrato tiene incidencia en el ámbito patrimonial en general, ya que lo extrapatrimonial no está sujeto propiamente a reglas que se sustentan esencialmente en la voluntad privada, sino en otras consideraciones. Así, el acuerdo matrimonial, por más que sea voluntario no es, estrictamente, un contrato, es mucho más que un contrato, corresponde a una institución social, y que se asocia a una determinada manera de enfocar las relaciones humanas inclusive desde la perspectiva del derecho natural.

Nuestra tesis radica en que una cosa es un enunciado general de lo que es un contrato, y otra es un enunciado específico sobre lo que puede versar un contrato. Es cierto que relación jurídica patrimonial no es sinónimo de obligación, incluye a esta última, pero es más que ella; empero, ¿eso es lo que se representó el legislador?

Sin embargo, no podemos obviar que el tema puede ser más complicado de lo que puede parecer a simple vista. El artículo 1351 de nuestro Código Civil tiene una redacción que es coincidente, palabras más, palabras menos, con la contenida en el Código Civil italiano de 1942, el mismo que constituyó ciertamente una de las grandes fuentes de inspiración del legislador nacional.

En efecto, el artículo 1321 del Códice contiene lo que es la noción legislativa de contrato: "El contrato es el acuerdo de dos o más partes para constituir, regular o extinguir una relación jurídica patrimonial entre ellas".

No podemos negar que el texto legislativo nacional es prácticamente una reproducción del texto italiano. En función a ello, debemos preguntarnos si hacemos nuestros los desarrollos jurisprudenciales y doctrinarios italianos sobre el particular, o no. $Y$ dejamos constancia que está fuera de toda discusión el nivel de desarrollo e influencia alcanzado progresivamente por la doctrina italiana en materia jurídica.

Postulamos que no corresponde hacer nuestros los señalados desarrollos, porque la conceptualización de lo que es un contrato tiene determinada orientación en el sistema civil italiano que es ajena a lo que se representó y propuso el legislador nacional, y a lo que representa nuestra tradición jurídica. En otras palabras, una coincidencia (porque eso es, una coincidencia) no implica que los alcances jurídicos del objeto contractual conforme a la legislación peruana deban ser asimilados a los de la legislación italiana. 
Recordemos que en materia de interpretación, más allá que la misma verse sobre la ley o sobre el contrato (dado que se trata finalmente de normas), lo literal es lo básico o elemental ${ }^{11}$; una interpretación será más consistente en la medida que incorpore otros criterios para dilucidar los alcances del respectivo texto. Asimismo, para fines de dicha interpretación no olvidemos la reflexión e invocación de De la Puente:

"Los Códigos no son una secuencia de disposiciones colocadas caprichosamente unas al lado de las otras, sino un todo orgánico en que cada una de sus normas, especialmente las que integran cada Sección, responde a un plan integral que las vincula íntima y ordenadamente, de tal manera que el cambio o supresión de una de ellas rompe la armonía del conjunto. Como los Códigos no pueden sustituirse rápidamente, pues son redactados con una vocación de permanencia, pienso que el camino adecuado es tomar una actitud más positiva e intentar la interpretación de la norma cuestionada utilizando especialmente los medios o elementos lógico y sistemático, para otorgarle su verdadero sentido a través de su relación con las demás en su conjunto. Sólo así lograremos conservar nuestro Código de acuerdo a la concepción que lo inspiró, adecuando meditadamente su espíritu a la constante evolución del Derecho, sin restarle coherencia y unidad $^{\prime 12}$. (Subrayado agregado).

Atendiendo a lo expresado, inclusive en la hipótesis que el legislador nacional hubiese pretendido reproducir en nuestro Código Civil la definición italiana de contrato, lo cierto es que ello no implica necesariamente que la respectiva norma debe ser leída e interpretada como se hace en otras latitudes, siendo que su lectura e interpretación debe realizarse en función a lo que el codificador peruano se representó en el marco de su regulación sobre contratos. Es más, conforme se propone en el presente trabajo, considerando que el Código Civil de 1984 es finalmente una unidad legislativa, esa lectura e interpretación también debe considerar, entre otros aspectos, lo que el codificador se representó en materia de derechos reales y en los diversos tipos de los contratos de cambio.

11 Sobre este tema, refiriéndose a la interpretación contractual (aunque los conceptos pueden aplicarse plenamente a la interpretación legal) expresa Roppo (En: El Contrato, $1^{a}$ edición, trad. Ariano Deho, Eugenia, Gaceta Jurídica, Lima, 2009, p. 440):

'Punto de partida es la interpretación textual, que se basa en el significado expreso de las palabras del texto y de sus conexiones sintácticas, según el código lingüístico compartido por la comunidad de hablantes a la que pertenecen los contratantes: a ella el intérprete no debe "limitarse", pero por ella debe sí pasar. La interpretación textual puede dejar márgenes de duda o ambigüedad semántica (cierta palabra puede tener dos diversos significados, ambos compatibles con el código lingüístico de referencia): en tal caso es natural -más bien indispensable- dirigirse a la búsqueda de la efectiva "común intención" de las partes, mediante datos extratextuales". (Subrayado agregado).

12 De la Puente y Lavalle, Manuel. De la Puente y Lavalle, Manuel, El contrato en general. Comentarios a la Sección Primera del Libro VII del Código Civil, Tomo III, Palestra Editores, Lima, 2011, pp. 667-668. 
En tal virtud, si se pretende oponer el artículo 1351 del Código Civil a lo establecido en su artículo 1402, y sin necesidad que deba invocarse el argumento lógico según el cual la norma especial debe predominar sobre la general -en la medida que hubiese incompatibilidad entre ellas (lo cual negamos)-, lo mínimo que se espera es revisar qué es lo que explica el actual tenor de la definición legislativa de contrato (artículo 1351 del Código Civil), ya que sólo así se podría proponer una lectura consistente con lo contenido en su artículo 1402.

4. El tenor actual del artículo 1351 del Código Civil sufrió, en el extenso proceso de elaboración del Código Civil, diversas modificaciones, de forma antes que de fondo. De manera sintética podemos sostener que bajo la expresión "relación jurídica patrimonial" no se puede sostener que el codificador nacional se representó lo que sí hizo en su momento el codificador italiano, dado que este último no exige que el contenido contractual sea obligacional para que pueda, en esos términos, generarse un sistema espiritualizado de transferencia convencional de propiedad, esto es, uno según el cual por el simple acuerdo de voluntades se transfiere (relativamente) la propiedad del bien sobre el cual recae el consentimiento. Pero en nuestro caso, más allá de la coincidencia de redacción, el legislador nacional no se representó dicho régimen de transferencia, sino que identificaba simplemente lo patrimonial con lo obligacional, siendo inclusive que en cierto momento se estableció que el contrato era un acuerdo obligacional de carácter patrimonial (definición redundante, por decir lo menos), cuando era suficiente haber señalado que era un acuerdo patrimonial, más allá que luego se precisase que, dentro de dicha patrimonialidad, el objeto (esto es, lo que se proponen las partes) es la creación, regulación o extinción de obligaciones y no otra clase de relaciones jurídicas. Propósito abstracto, es cierto, pero que es jurídicamente consistente.

Y para ello es pertinente tener en cuenta que, de acuerdo al anteproyecto (1980) de la "Comisión Reformadora", propuesto por el profesor Max Arias-Schreiber, en materia de Fuentes de las Obligaciones, su artículo 1 sancionaba lo siguiente: "El contrato es el acuerdo de dos o más partes para crear, regular o extinguir entre sí obligaciones de carácter patrimonial".

Dicho texto quedó, siempre a nivel de "Comisión Reformadora", en el artículo 1370 del respectivo proyecto (1981) según lo siguiente: "El contrato es el acuerdo de dos o más partes para crear, reglar, modificar o extinguir entre sí obligaciones de carácter patrimonial".

En otras palabras, a nivel de la "Comisión Reformadora" la representación del legislador sobre lo que era un contrato no era sino la de un acuerdo obligacional, con carácter (por consiguiente) patrimonial. El propio Arias-Schreiber lo destaca en su obra "Exégesis" cuando manifiesta que:

"Aunque la mayoría de los códigos no definen y dejan esta materia a los tratadistas y docentes, el Código vigente, fiel a su concepción pedagógica 
lo ha hecho y señala en el artículo 1351, que es el acuerdo destinado a crear, regular, modificar y extinguir una relación jurídica de carácter patrimonial, es decir, una relación obligatoria" ${ }^{13}$. (Subrayado agregado)

Podremos estar de acuerdo o no con el sentido de la definición sobre la base de nuestro entendimiento sobre si correspondía o no introducir la señalada definición, o sobre sus alcances, pero no podemos negar que para el entendimiento del codificador (al menos a nivel de "Comisión Reformadora") relación jurídica patrimonial era relación obligacional. En otras palabras, para el legislador nacional, el contrato se asocia necesariamente a obligaciones. $\mathrm{Y}$ si el contrato es el título que permite una ulterior transferencia convencional de propiedad, bien puede concluirse que para lograr esta última se requiere de la observancia de un modo o manera para alcanzarla, que sería finalmente la conducta esperada a cargo de deudor de la transferencia. Bien sabemos que, conforme ya hemos expresado, la cobertura de una relación jurídica patrimonial puede ser más amplia que la de contenido meramente obligacional; empero, el legislador nacional no hizo tal diferencia.

Los alcances del artículo 1351 del Código Civil puedan probablemente explicarse en función a la primera parte de su artículo 140 ('El acto jurídico es la manifestación de voluntad destinada a crear, regular, modificar o extinguir relaciones jurídicas"), esto es, porque se habría pretendido destacar que el acto jurídico puede ser tanto en el ámbito patrimonial como extrapatrimonial, mientras que lo contractual sólo puede darse en el ámbito patrimonial; empero, más allá de ello, lo cierto es que el codificador al emplear las palabras "relación jurídica patrimonial" estaba refiriéndose a "relación obligacional".

¿Por qué esa identidad, en el sentido que para el codificador de la "Comisión Reformadora" relación jurídica patrimonial era sinónimo de relación obligacional?

No debe olvidarse que en materia de obligaciones el interés es la noción matriz, que permite dar sentido funcional al contenido de la respectiva relación jurídica ${ }^{14}$. Las obligaciones (como relaciones jurídicas) se estructuran sobre la base de un determinado interés, el de una parte (acreedor) que pretende algo que está al alcance, en la esfera patrimonial, de su contraparte (deudor), siendo la prestación aquello que se pretende mediatamente más allá que sea de ejecución positiva (dar, hacer) o negativa (no hacer). Dado que las obligaciones pueden ser de fuente autónoma (voluntaria) o heterónoma (legal), el medio ordinario para generarlas es mediante el acuerdo de los interesados, de manera que todo contrato es literalmente instrumental,

13 Arias Schreiber Pezet, Max, Exégesis del Código civil peruano de 1984, tomo I (Contratos: Parte general), colab. Cárdenas Quirós, Carlos; Arias-Schreiber M, Angela y Martínez Coco, Elvir; Gaceta Jurídica Editores, Lima, 1995, pp. 43-44.

14 Bianca, Massimo, El interés (traducción libre a cargo del profesor Gastón Fernández de la parte pertinente del libro Diritto Civile - volume 4: L'obbligazione). En: Ius et Veritas, revista editada por estudiantes de la Facultad de Derecho de la Pontificia Universidad Católica del Perú, n 9, Lima, 1994, pp. 111-115. 
no sólo porque sirve para fines del tráfico de bienes y servicios, dotándolo de seguridad, sino porque lo que pretende inmediatamente es instituir una determinada clase de relación jurídica, o sobre la base que la misma ya exista, regularla o extinguirla.

Atendiendo a dicha consideración, a nivel de la "Comisión Revisora", se acordó finalmente, en el artículo 1318 del proyecto publicado en febrero de 1981 (segundo proyecto, si lo comparamos con el publicado por la "Comisión Reformadora" en 1981, que vendría a ser el primer proyecto), lo siguiente: "El contrato es el acuerdo de dos o más partes para crear, regular, modificar o extinguir una relación jurídica patrimonial".

Ese es el texto que corresponde al artículo 1351 del Código Civil vigente actualmente.

5. Para quienes sostienen que el artículo 1351 del Código Civil peruano se inspira en la legislación italiana y debe ser aplicado en ese contexto, hay cierto detalle que no puede obviarse. Sobre la base que el codificador nacional, tanto a nivel de "Comisión Reformadora" como de "Comisión Revisora", se representó al contrato como fuente de obligaciones, cuidó de introducir una definición expresa de lo que es el objeto contractual. El artículo 1402, por consiguiente, zanja cualquier discrepancia sobre lo que es materia del acuerdo contractual, estableciendo que debe ser obligacional.

Conforme a ello, el artículo 1351 del Código Civil, no sólo por razones de antecedentes en su proceso de redacción (que no deben dejarse de apreciar), sino por elemental cuestión sistemática, no puede ser leído e interpretado sin considerar al menos los alcances del artículo 1402 del mismo cuerpo normativo.

El legislador nacional cuidó de enunciar, explícitamente, que el objeto de todo contrato (más allá de la manera en que pueda clasificarse, sea por su perfeccionamiento constitutivo, por su funcionalidad, por sus efectos, por su duración, etc.) es necesariamente obligacional. Enunciado que el Código Civil italiano no recoge porque, insistimos, parte de una premisa que no corresponde a nuestra legislación histórica ni a la voluntad uniforme del legislador nacional.

En efecto, de acuerdo al anteproyecto (1980) de la "Comisión Reformadora" en materia de Fuentes de las Obligaciones, su artículo 43 sancionaba que: "El objeto del contrato consiste en crear, regular o extinguir obligaciones de dar, hacer o no hacer".

Siendo que dicho texto quedó, siempre a nivel de "Comisión Reformadora", en el artículo 1418 del respectivo proyecto (1981) según lo siguiente: "El objeto del contrato consiste en crear, reglar, modificar o extinguir obligaciones de dar, hacer o no hacer".

Sobre la base de las premisas que explicaban esa redacción, el artículo 1367 del proyecto de la "Comisión Revisora" estableció: "El objeto del contrato consiste en crear, regular, modificar o extinguir obligaciones".

Texto que fue incorporado finalmente en el artículo 1402 del Código Civil: "El objeto del contrato consiste en crear, regular, modificar o extinguir obligaciones". 
Se suprimió la indicación sobre el "dar, hacer o no hacer" porque en rigor corresponden al contenido de las prestaciones, que son las actuaciones debidas en función de la relación obligacional.

En otras palabras, tanto a nivel de la "Comisión Reformadora" como de la "Comisión Revisora", y no obstante la diversidad de sus respectivas composiciones, la representación sobre lo que se pretende (objeto como sinónimo de fin o propósito común) con la celebración de un contrato era uniforme, entendiéndose que el objeto de todo contrato poseía definitivamente carácter obligacional.

Si el objeto es obligacional, resulta manifiesto que la relación jurídica patrimonial en que consiste un contrato (artículo 1351 del Código Civil peruano) no puede ser sino obligacional, pese a que lo patrimonial pudiese sugerir -textualmente- algo mucho más amplio. Hubiese sido probablemente lo más adecuado que entre los artículos 1351 y 1402 hubiese habido absoluta simetría en la redacción, refiriéndose por igual a relaciones jurídicas obligacionales, empero, ello no autoriza a desconocer que ambas reglas fueron redactadas bajo un mismo entendimiento, un mismo espíritu. No olvidemos en todo caso que, conforme al refrán ruso, lo perfecto es enemigo de lo bueno. Aunque no exista una coincidencia en el empleo de las palabras, lo importante es lo que hay detrás de estas últimas, para lo cual la interpretación de sus antecedentes de redacción resulta fundamental, así como una atenta lectura de las diversas normas del cuerpo legislativo tomado como unidad.

6. Y para que no quede duda alguna, el objeto contractual no sólo se enuncia en el artículo 1402 del Código Civil vigente, sino que además se reitera en su artículo 1403, cuando se diferencia inobjetablemente lo que es el atributo del objeto contractual (la obligación), estableciéndose que debe ser conforme al ordenamiento jurídico (esto es, la obligación debe ser lícita), de lo que son los atributos de esa conducta humana sobre la cual se posee interés relevante y digno de protección (la prestación), señalándose que la misma debe ser posible, sin perjuicio -desde luego- que además debe ser cierta (determinada o determinable) y estimable pecuniariamente.

Resulta pertinente remitirnos, nuevamente, a los textos que permiten apreciar qué es lo que se representó sucesivamente el codificador.

De acuerdo al anteproyecto (1980) de la "Comisión Reformadora" en materia de Fuentes de las Obligaciones, sus artículos 44 y 51 sancionaban, respectivamente, lo siguiente: "La obligación que es objeto del contrato debe ser lícita (...) La prestación materia de la obligación creada por el contrato debe ser posible".

El tenor del señalado artículo 44 quedó, siempre a nivel de "Comisión Reformadora", incorporado en el artículo 1419 del respectivo proyecto (1981) según lo siguiente: "La obligación que es objeto del contrato debe ser lícita".

Se omitió regular lo concerniente a las características de la prestación, objeto material o contenido de la respectiva relación obligacional. 
Por último, ya a nivel de la "Comisión Revisora" se retomaron los artículos 44 y 51 de la referida ponencia del profesor Max Arias-Schreiber, y refundiéndolos, se estableció lo siguiente en el artículo 1368 del proyecto de Código Civil publicado en febrero de 1981: "La obligación que es objeto del contrato debe ser lícita. El objeto de la prestación en que consiste la obligación debe ser posible".

Dicho texto, palabras más o palabras menos, es el que figura actualmente en el artículo 1403 del Código Civil: "La obligación que es objeto del contrato debe ser lícita. La prestación en que consiste la obligación y el bien que es objeto de ella deben ser posibles".

Se aprecia, en consecuencia, que el legislador de manera consistente se representa, desde el anteproyecto Arias-Schreiber hasta la versión finalmente aprobada como Código Civil, que el objeto del contrato es la obligación, y como ésta es una relación jurídica, la misma sólo requiere ser lícita, siendo que el atributo de posibilidad (se entiende física) es propio de la actuación humana comprometida, esto es, de la prestación, que es la actividad en sí orientada a obtener el bien o servicio.

Es más, los artículos 1407, 1409 y 1410 del Código Civil ${ }^{15}$, todos ellos confortantes del título legislativo referente al "Objeto del contrato", reiteran el mismo concepto: la obligación es el objeto del contrato, siendo que la prestación (conducta debida) es el contenido (material) de esta última.

7. Hasta acá estamos ante un recuento de antecedentes que forman parte del proceso de elaboración del Código Civil de 1984, el cual es más que ilustrativo; empero, podría considerarse que aquél no arroja una conclusión definitiva, dado que el espíritu de la ley no es su letra, siendo que esta última adquiere cierta autonomía, ya que predomina lo expresado frente a lo querido. En ese sentido, resulta necesario recurrir a otros criterios para fines de interpretación legal.

15 Artículo 1407.- Si la determinación de la obligación que es objeto del contrato es deferida a un tercero y no resulta que las partes quisieron remitirse a su mero arbitrio, el tercero debe proceder haciendo una apreciación de carácter equitativo. (Subrayado agregado).

Artículo 1409.- La prestación materia de la obligación creada por el contrato puede versar sobre:

1.- Bienes futuros, antes de que existan en especie, y también la esperanza incierta de que existan, salvo las prohibiciones establecidas por la ley.

2.- Bienes ajenos o afectados en garantía o embargados o sujetos a litigio por cualquier otra causa. (Subrayado agregado).

Artículo 1410.- Cuando la obligación creada por el contrato recae sobre un bien futuro, el compromiso de entrega queda subordinado a su existencia posterior, salvo, que la obligación verse sobre una esperanza incierta, caso en el cual el contrato es aleatorio.

Si la falta de entrega obedece a causas imputables al obligado, el acreedor puede recurrir a los derechos que le confiere la ley. (Subrayado agregado). 
Sobre el particular no debemos soslayar la explicación que proporciona Manuel de la Puente con relación a los alcances del objeto contractual bajo el Código Civil peruano $\mathrm{y}$, por consiguiente, sobre la improcedencia de postular que dicho objeto no requiere ser obligacional (pese a la absoluta claridad, entre otros, de los artículos 1402 y 1403 del Código Civil) siendo suficiente que sea patrimonial (atendiendo a los alcances literales del artículo 1351 del Código Civil).

¿Por qué el Código Civil peruano establece que el objeto contractual, como sinónimo de propósito de las partes, de fin del negocio, debe ser obligacional?

El maestro destaca, de un lado, que se quiso dejar explícita mención que al representar todo contrato un instrumento, al representar un vehículo de cooperación orientado a satisfacer determinado interés negocial, lo que las partes se representan y proponen -para fines de celebrar un contrato (función normativa ${ }^{16}$ : autorregulación de intereses)- es establecer una vinculación con el deudor, una determinada relación jurídica patrimonial, de tal manera que pueda exigirle cierta actividad. Exigencia en sentido estricto, por lo que ante un incumplimiento el acreedor pueda recurrir a los diversos remedios que están orientados a cautelar sus intereses ${ }^{17}$, los que se extienden desde la posibilidad de exigir el cumplimiento, de generarlo forzosamente, de obtener la ejecución debida por vías alternas, por cuenta del deudor, etc., hasta la posibilidad de optar (concurso electivo) por la resolución, sujeto esto último a los requisitos pertinentes. En otras palabras, que esa determinada relación jurídica es una obligación, auténtica vinculación o encadenamiento del deudor al acreedor. Y de otro lado ( $y$ esto es a nuestro juicio lo más significativo, pero curiosamente lo que menos se destaca), se pretendió cerrar la discusión en nuestro medio sobre la posibilidad de configuración de contratos con efectos reales o traslativos, esto es, de aquellos que por el sólo mérito de su celebración implican la transferencia de propiedad del bien materia del acuerdo (al margen que sean muebles o inmuebles), siendo que el legislador nacional descartó la denominada espiritualización de la transferencia convencional de propiedad. Por lo tanto, la celebración de un contrato, inclusive tratándose de los acuerdos de cambio, al margen de su onerosidad o gratuidad, sólo implica la generación de la obligación de transferir propiedad, de manera que hay un compromiso prestacional (el débito o deuda) a ser observado por el deudor en beneficio del interés del acreedor.

16 'En realidad el negocio, y por lo tanto el contrato, nacen ya como actos normativos en el plano jurídico, porque (sic) los privados expresan, con el contrato, la potestad, atribuida a ellos por el ordenamiento, de crear normas jurídicas. El contrato nace como fuente de obligaciones, y es tal porque tiene naturaleza de fuente normativa. Si él créase vínculos solamente en el plano prejurídico no sería un contrato". Ferri, Luigi, "Lecciones sobre el contrato". En: Curso de Derecho Civil, presentación, notas y edición a cargo de Rómulo Morales Hervias y Leysser L. León, trad. de Nélvar Carreteros Torres, $1^{a}$ edición, Editora Jurídica Grijley, Lima, 2004, pp. Ivi-Ivii.

17 Resulta pertinente remitirnos a los artículos 1219 y 1428 del Código Civil, entre otros. 
Remitiéndose a la Exposición de Motivos y Comentarios elaborada por los juristas que integraron la "Comisión Reformadora"18, en la que se diferencia claramente que una forma de entender al objeto contractual es que recae en la prestación, y otra, en la relación jurídica (de la cual se desprende la prestación), habiéndose optado por esta última, De la Puente manifiesta:

"(...) [E]l legislador no siguió el cómodo camino de abstenerse de tomar partido y dejar a la doctrina la determinación del objeto del contrato, con todas las dudas y divergencias de opinión a que ello da lugar, sino que optó conscientemente, entre varias alternativas, por una posición que, sin ser necesariamente indiscutible, consideró la más válida.

\section{( ...)}

Se ha visto (...) que existen tres planteamientos sustentados por juristas de nota con plausibles razones, sobre el objeto del contrato, que unos ubican en la obligación, otros en la prestación y el resto en el bien o servicio.

Ante esta realidad, el codificador peruano, que bien pudo abstenerse de definir el objeto del contrato o bien adoptar la posición de su homólogo italiano de limitarse a indicar que tal objeto debe ser posible, lícito, determinado o determinable, decidió (...) elegir entre esos planteamientos y optó por el de considerar que el objeto del contrato es crear, regular, modificar o extinguir obligaciones $^{\prime 19}$. (Subrayado agregado).

Es más, atendiendo a los alcances ya comentados de los artículos 1351 y 1402 del Código Civil, el maestro De la Puente prosigue expresando:

"Al comentar el artículo 1351 del Código Civil peruano se vio que en todos sus antecedentes, hasta el artículo 1370 del primer Proyecto, inclusive, se habló de obligaciones de carácter patrimonial, y que sólo a partir del artículo 1318 del segundo Proyecto se empezó a hacer referencia a una relación jurídica patrimonial. Sin embargo, parece que esta modificación no se debió a un cambio de criterio sobre la finalidad del contrato como fuente de obligaciones, tan es así que tanto en el segundo Proyecto como en el Código civil se conservó el artículo referente a que el objeto del contrato es crear obligaciones.

18 La "Exposición de Motivos y Comentarios", de manera específica tratándose del libro "Fuentes de las Obligaciones" del Código Civil, fue incorporada en la publicación (seis tomos) que realizó Delia Revoredo de Debakey (como compiladora) bajo el título bibliográfico "Código Civil", Okura Editores S.A. Lima, 1985. Tratándose de la Sección Primera (Contratos en general) del libro "Fuentes de las Obligaciones", la explicación exegética estuvo a cargo de Max Arias-Schreiber Pezet, con la colaboración de Carlos Cárdenas Quirós y Angela Arias-Schreiber Montero.

19 De la Puente y Lavalle, Manuel. De la Puente y Lavalle, Manuel, El contrato en general. Comentarios a la Sección Primera del Libro VII del Código Civil, Tomo II, $2^{a}$ edición, Palestra Editores, Lima, 2011, p. 21. 
Esto pone de manifiesto que para el codificador peruano la expresión "relación jurídica patrimonial" tiene un sentido distinto que le otorga el codificador y la doctrina italianos, o sea que se refiere a una relación obligacional, con lo cual estoy de acuerdo.

Sin embargo, para evitar que al interpretarse el artículo 1351 se le dé un sentido distinto al que realmente tiene, el codificador peruano ha procedido bien al establecer que el objeto del contrato consiste en crear, regular, modificar o extinguir obligaciones, con lo cual ha eliminado la posibilidad de que se piense que el contrato puede producir efectos reales ${ }^{\prime \prime 20}$. (Subrayado agregado).

8. Habiendo transcurrido más de treinta años pareciera que no caló suficientemente ese propósito explícito. Es más, cuando se genera el debate sobre el régimen de transferencia convencional de propiedad adoptado por el Código Civil, el cual presupone la existencia de un contrato, no se suele enmarcar dicho debate en función a las normas que regulan el objeto contractual y a lo que el legislador se representó, siendo tendenciosamente más cómodo quedarse con la definición general de contrato que permitiría respaldar la tesis del contrato traslativo.

A la fecha subsiste la discusión sobre cuál es el objeto contractual conforme a la ley peruana y para ello se recurre a toda serie de argumentos, atendiendo sobre todo a la comparatística. Sin embargo, lo que llama la atención es que pareciera desconocerse lo que fue la ratio legis del artículo 1402 del Código Civil: En primer lugar, que el contrato, todo contrato, es un vehículo de cooperación intersubjetiva, por lo que busca generar una relación obligacional para que, en función de ella, el acreedor pueda exigir cierta prestación (conducta) al deudor, satisfaciendo su interés negocial. Y en segundo lugar (y esto es lo concluyente), que se descarta definitivamente en nuestro país la posibilidad jurídica de la generación de contratos con efectos reales, traslativos o espiritualizados, de manera que todo contrato de cambio (tipificado o no) genera exclusivamente efectos personales, crediticios u obligaciones, de lo cual se desprende que la transferencia de propiedad no se produce en etapa de celebración sino de ejecución contractual, demandando de una actuación por parte del obligado a transferir.

Es más, al margen de la discusión académica que pueda mantenerse sobre la materia (no nos olvidemos que hay de por medio un tema de opción del codificador de 1984), pareciera que se pone énfasis en la simple expresión, en la literalidad de las normas del Código Civil, antes que, con "una actitud más positiva" postular una lectura sistemática teniendo en cuenta la orientación adoptada y que explica el uso de las palabras, sosteniéndose que sobre la base del artículo 1351 del Código Civil es perfectamente posible un sistema espiritualizado de transferencia de propiedad, por lo

20 De la Puente y Lavalle, Manuel, El contrato en general. Comentarios a la Sección Primera del Libro VII del Código Civil, Tomo II, 2a edición, Palestra Editores, Lima, 2011, p. 25. 
que el artículo 949 del Código Civil no exige de modo alguno porque la celebración misma del contrato conlleva la traslación de propiedad.

Entendemos y postulamos que las reglas legales sobre transferencia (convencional) de propiedad deben ser interpretadas y aplicadas en función a las reglas de contratos, dado que regulan las consecuencias de haberse celebrado un contrato de cambio, esto es, para fines de transferir titularidades sobre bienes, del derecho de propiedad. Conforme a ello, no se puede pretender que la consecuencia explique la causa, siendo que lo lógico es más bien que la causa explique la consecuencia.

El legislador peruano tuvo en sus manos al modelo legislativo italiano, lo replicó en muchos aspectos, pero en otro no, siendo que muchas figuras las acomodó a lo que bien podríamos identificar como la tradición legislativa del país. El legislador nacional optó, asumió un determinado régimen de objeto contractual. No resulta honesto que obviemos dicha decisión y tratemos de leer e interpretar al Código Civil como si contuviese un conjunto de normas contradictorias entre sí, de manera que postulemos que la discusión sobre los alcances del objeto contractual no quedó zanjada y, que en función a ello, si bien los contratos pueden presentar contenido obligacional, en rigor no lo demandan.

En esa discusión sobre los alcances del Código Civil, más allá de nuestras propias convicciones, y de nuestro propio juicio sobre si la opción del codificador de 1984 respecto al objeto contractual fue la más adecuada, debemos actuar con eticidad. No sólo respetando la opinión ajena, por más que pudiésemos considerarla equivocada, esto es, sin descalificarla por el solo hecho que no sea coincidente con la propia, sino exponiendo los criterios interpretativos que existen, lo cual presupone enunciar los antecedentes de las normas y lo que se representó el legislador al momento de la redacción final, apreciando finalmente la coherencia normativa sobre la materia que presenta el Código Civil como cuerpo legislativo. Conforme a ello, bien puede concluirse que el artículo $949^{21}$ del Código Civil -cuyo texto sugeriría la adhesión a un régimen traslativo- debe entenderse en función a las demás normas del Código Civil, siendo que carece de sustento recurrir al artículo 1351, ya que según hemos destacado, más allá de las palabras empleadas, el legislador se refería a las relaciones obligacionales.

9. Dado que postulamos que el objeto de todo contrato, desde una óptica de funcionalidad normativa, tiene por objeto a una obligación -como relación jurídica específica-, resulta pertinente destacar estos alcances.

21 "La sola obligación de enajenar un inmueble determinado hace al acreedor propietario de él, salvo disposición legal diferente o pacto en contrario". Sostenemos que el texto "sugeriría" un sistema espiritualizado de transferencia de propiedad inmueble, porque en realidad no es así, si uno cuida de estudiar y apreciar el criterio legislativo que está detrás de dicho texto. 
En palabras de Díez-Picazo y Gullón:

"La obligación es una situación bipolar, que se encuentra formada, por un lado, por la posición de una persona llamada deudor, y por otro, por la posición de otra persona distinta llamada acreedor. El acreedor es titular de un derecho subjetivo (derecho de crédito), que le faculta para exigir frente al deudor lo que por éste es debido (prestación). Al mismo tiempo, como medida complementaria, el acreedor se ve embestido de la posibilidad, en caso de incumplimiento, de proceder contra los bienes del deudor, así como investido también de una serie de facultades para la defensa de sus intereses. La segunda faceta o el segundo polo es la posición del deudor. El deudor es sujeto de un deber jurídico (deuda), que le impone la observancia del comportamiento debido y le sitúa en el trance de soportar, en otro caso, las consecuencias de su falta.

Como situación de dos polos, la "obligación" es una relación jurídica (relación obligatoria). La relación obligatoria es un cauce o un instrumento para que las personas puedan realizar actividades de cooperación social y, más concretamente, para que puedan intercambiar bienes y servicios" ${ }^{22}$.

Conforme a lo enunciado, y por las razones históricas expuestas al inicio de este trabajo, podemos sostener que la decisión del codificador nacional de regular un objeto contractual no fue una decisión accidental sino que representó una determinada y, sobre todo, consciente visión de la realidad y de la convivencia social.

Se genera una relación, no sólo social, sino jurídica, cuando finalmente se entrelazan dos personas en función a ciertas circunstancias, reconocidas por el derecho y de las cuales se desprenden ciertas consecuencias ${ }^{23}$. Las relaciones jurídicas, desde dicha perspectiva, son necesariamente subjetivas, entre sujetos de derecho, con la representación de las consecuencias legales en caso de inobservancia, empero pueden categorizarse bajo diversas modalidades ${ }^{24}$. Así, por ejemplo, no es lo mismo una relación poder-deber que un crédito-deuda. La primera está signada con una titularidad que puede ser opuesta directamente a cualquier persona, erga omnes, de manera que toda persona (perteneciente al universo de aplicación del poder) debe respetarla. La segunda se caracteriza por una titularidad específica que sólo puede ser opuesta directamente a determinada persona, inter partes, por lo que sólo el deudor

22 Díez-Picazo, Luis y Gullón, Antonio. Sistema de Derecho Civil, vol. II, tomo 1 - El contrato en general. La relación obligatoria, 10a edición, Editorial Tecnos (Grupo Anaya S.A.), Madrid, 2013, p. 111.

Roppo, Vincenzo. El Contrato, $1^{\text {a }}$ edición, trad. Ariano Deho, Eugenia, Gaceta Jurídica, Lima, 2009, pp. 36-37. Normas, sujetos y relación jurídica, $1^{\text {a }}$ edición, traducción Hinestrosa, Fernando, Universidad Externado de Colombia, Bogotá, 1992, pp. 351-357. 
está sometido al respectivo acreedor, atendiendo a que éste tiene un interés directo y exclusivo hacia él ${ }^{25}$.

Un contrato, como expresión concreta del poder negocial que posee toda persona para acordar una determinada relación jurídica de existir intereses relevantes o dignos de tutela $^{26}$, implica que es el instrumento necesario para que una determinada persona pueda exigir algo a otra. Si bien el interés de una persona puede radicar en lograr una acción, o una abstención de otra, o la entrega de una determinada cosa, no es menos cierto que para poder exigirlo debe haber un determinado enlace. Por ello es que se sostiene que el objeto del contrato es obligacional, porque lo que se pretende jurídicamente (objeto) es crear (regular, modificar o extinguir) dicho enlace, a ello va encaminada la declaración de voluntad ${ }^{27}$ común.

La obligación derivada del contrato implica una determinada relación jurídica que deriva en situaciones subjetivas precisas para quienes por elemental relatividad contractual $^{28}$ son las partes sustantivas o materiales del respectivo acuerdo: una de ellas (acreedor) asume la titularidad de una situación subjetiva de ventaja que es el crédito, y la otra (deudor), la situación subjetiva de desventaja que es la deuda o débito. Siendo que la relación obligacional presenta ambas situaciones, como anverso y reverso de una misma moneda, se entiende que el crédito permite al acreedor poder exigir al deudor, sólo al deudor y a nadie más que al deudor (por el efecto relativo del vínculo) que realice cierta actividad, positiva o negativa, para satisfacer su interés, de manera que la asunción de la deuda está orientada exclusivamente a satisfacer dicho

25 Morales Hervias, Rómulo, "Situaciones jurídicas subjetivas". En: Advocatus, revista editada por alumnos de la Facultad de Derecho de la Universidad de Lima, n 19, Lima, 2009, pp. 356-359. Lo cual puede válidamente asociarse a la noción de causa negocial objetiva.

Resulta pertinente destacar que la declaración es precisamente una exteriorización de voluntad que persigue o pretende generar cierto efecto. En el marco de la autonomía privada, lo que pretenden las partes, a través de sus declaraciones coincidentes, es justamente un efecto: una relación jurídica vinculante, obligacional; de manera que ella sea el título sobre el cual pueda exigirse la prestación debida mediante la cual se satisface el interés del acreedor. Nos remitimos a Moreyra García-Sayán, Francisco, El acto jurídico según el Código Civil peruano. Curso teórico, histórico y comparativo, Fondo Editorial de la Pontificia Universidad Católica del Perú, Lima, 2005, pp. 103-115, así como a Espinoza Espinoza, Juan. Acto jurídico negocial. Análisis doctrinario, legislativo y jurisprudencial, $1^{\text {a }}$ edición, Gaceta Jurídica, Lima, 2008, pp. 49-68. Resulta interesante que aunque puedan considerarse sinónimos, entre manifestación y declaración de voluntad se puede apreciar una fina y sutil diferencia jurídica, la declaración es una manifestación de voluntad, orientada voluntariamente para producir determinados efectos jurídicos. Postulamos que un contrato demanda de declaración antes que de una simple manifestación de voluntad.

Artículo 1363 del Código Civil, conforme al cual "Los contratos sólo producen efectos entre las partes que los otorgan (...)". 
interés. Por ello es que en caso de cumplimiento o pago, calificada doctrina ${ }^{29}$ señala que la ejecución cumple una doble funcionalidad, satisfactiva y extintiva, lo primero orientado netamente al interés del acreedor, y lo segundo que, sobre la base que el acreedor ya fue satisfecho en su interés, nada justifica la subsistencia de la vinculación, de manera que ésta se extingue, el pago pone fin a la relación obligacional que fuese generada en su momento por el contrato, aunque ambas funciones no operan necesariamente unidas, ya que pueden estar disociadas.

"El pago, como efecto, es un concepto ambivalente. Su ambivalencia proviene de las distintas funciones que puede llevar a cabo. El Código civil español establece en su art. 1.156 que "las obligaciones se extinguen (...) por el pago o cumplimiento (...)". He aquí su primera y más importante función. Parece, por tanto, que siempre que una obligación se pague o se cumpla, la deuda se extingue y el deudor queda liberado por la entrega de la cosa o el hecho de la prestación en que la obligación consistía. Hay, consiguientemente, una perfecta simetría entre la satisfacción del interés del acreedor, que ve realizado su crédito, y la liberación del deudor, que ve extinguida su deuda.

\section{(...)}

Sin embargo, hay casos en los cuales la extinción de la obligación del deudor no viene dada como consecuencia de la satisfacción del interés del acreedor, sino más bien prescindiendo de la misma.

\section{(..)}

Inversamente, cabe considerar igualmente algún caso en que la función satisfactiva del pago venga desligada de la función extintiva del mismo, pero ahora a expensas de esta última"30.

10. Por último, debe destacarse que la objeción a la opción nacional sobre el objeto contractual obligacional no se limita a un simple tema de textualidad normativa (atendiendo a los alcances del artículo 1351 del Código Civil), porque también se postula ${ }^{31}$ que el artículo 1402 del Código Civil peruano representa un error conceptual, al confundir lo que es el objeto del acto (del contrato) con el objeto de la relación (de la obligación). Así, sostiene Gabrielli lo siguiente:

29 Hernández Moreno, Alfonso. El pago del tercero, Bosch Casa Editorial S.A., Barcelona, 1983, pp. 75-86. Nos remitimos adicionalmente a nuestro trabajo "Interés motivacional y efectos del pago", publicado generosamente en: Ius et Praxis, revista de la Facultad de Derecho de la Universidad de Lima, n 35, Lima, 2004, pp. 25-39.

Hernández Moreno, Alfonso. El pago del tercero, Bosch Casa Editorial S.A., Barcelona, 1983, pp. 75-81.

31 Gabrielli, Enrico, Estudios sobre teoría general del contrato, trad. Morales Hervias, Rómulo y Vásquez Rebaza, Walter, Jurista Editores, Lima, 2013, p. 260. 
"En el derecho latinoamericano del contrato en general el tema del contenido y del objeto ha sido codificado de forma distinta, según el tipo de planteamiento que los ordenamientos individuales han acogido, recibiendo las líneas guía ofrecidas por las experiencias jurídicas de los países europeos, o bien según cómo, en el transcurso del tiempo, han elaborado autónomamente la sistematización del hecho jurídico hipotético (fattispecie).

Al describir el marco normativo, puede hacerse una primera clasificación entre los códigos que contemplan una parte general sobre el acto o sobre el negocio jurídico y una parte especial sobre el contrato, y los códigos que, por el contrario -siguiendo el modelo del código italiano, que como es sabido, deriva su planteamiento del Code Napoleón- regulan solamente la parte sobre el contrato en general.

Por ejemplo, en la primera categoría se ubica el Código Civil peruano, el cual -en su última formulación- contiene una norma en materia de acto jurídico y un específico título en materia de objeto del contrato (art. 1402 cód. civ.), en el cual, no obstante (cuando se dice que "el objeto del contrato consiste en crear, regular, modificar o extinguir obligaciones") se comete un error conceptual al confundir el objeto del acto (esto es, del contrato) con el objeto de la relación (esto es, la obligación)" ${ }^{32}$.

Es más, en nuestro medio, el profesor Taboada ${ }^{33}$ consideraba, desde una perspectiva dogmática, que los artículos 1402 y 1403 responden a una determinada visión desde un cuestionable enfoque propio del derecho de contratos, más no desde la rigurosidad abstracta de la teoría del negocio jurídico, destacando, por un lado, que la definición del objeto contractual es errada porque la relación obligatoria es la consecuencia de la celebración del contrato, por lo que no puede ser su objeto, dado que por este último puede entenderse en doctrina tanto un elemento, presupuesto o requisito (tema estructural), siendo que, de otro lado, se trata de una definición que juzgaba innecesaria, porque debería estarse al objeto del negocio jurídico, dado que un contrato es una especie de dicho género, sin perjuicio que estimaba innecesario que se incorporen definiciones en un cuerpo legislativo.

Pero, ante dichos cuestionamientos, no debe olvidarse que se está ante una obra legislativa, y que muchos de sus contenidos corresponden a opciones normativas con una determinada finalidad, siendo esto último lo que debe prevalecer para fines de interpretación.

32 Gabrielli, Enrico, Estudios sobre teoría general del contrato, trad. Morales Hervias, Rómulo y Vásquez Rebaza, Walter, Jurista Editores, Lima, 2013, pp. 259-260.

33 Taboada Córdova, Lizardo, "La problemática del objeto del negocio jurídico en la dogmática jurídica moderna y la necesidad de unificar la noción de objeto del contrato y del acto jurídico dentro del Código Civil peruano". En: Ius et Veritas, revista editada por estudiantes de la Facultad de Derecho de la Pontificia Universidad Católica del Perú, n 5, Lima, 1992, pp. 53-60. 
Si entendemos que el acto jurídico es el contrato mismo, lo que se busca con éste es definitivamente generar una determinada relación jurídica, de contenido obligacional, conforme -entre otros- a los artículos 1351, 1402 y 1403 del Código Civil peruano; alcanzado el respectivo acuerdo, lo que subsiste es la relación jurídica (más allá que sea de ejecución inmediata e instantánea, o diferida), siendo que la misma versa sobre una determinada conducta positiva o negativa que puede ser exigida por el acreedor al deudor, lo cual radica en la prestación debida, para fines que el acreedor adquiera los beneficios correspondientes que le permitan satisfacer su interés. Recordemos que "objeto" tiene varias acepciones en nuestro idioma. Es literalmente objeto contractual tanto lo que se pretende (la relación jurídica obligacional) como el bien o servicio sobre el cual recae finalmente el interés del acreedor. El objeto contractual peruano no es estrictamente la prestación, ni los bienes o servicios sobre los que recae esta última (recordemos lo concerniente al lenguaje corriente). El objeto contractual es la relación obligacional porque el contrato como hecho (no como norma, no como documento ${ }^{34}$ ) genera, vía consentimiento, la respectiva relación jurídica, y con ello cumple su único cometido.

En palabras de Larroumet ${ }^{35}$ resulta pertinente considerar que:

"El encuentro de las voluntades de las partes contratantes tiene por objeto vincularlas jurídicamente, esto es, crear obligaciones. (...) Sin embargo, es preciso tener en cuenta que el contrato a veces puede tener por objeto constituir un derecho real o transferir un derecho o una obligación. En realidad, el objeto del contrato se confunde con su efecto.

El Código Civil $^{36}$ no distingue entre el objeto del contrato y el objeto de la obligación, creada por el contrato.

Algunos autores critican este método y se proponen distinguir entre el objeto del contrato y el objeto de la obligación. Mientras que el objeto de la obligación es la prestación que el deudor debe cumplir (...), el objeto del contrato estaría constituido por la operación jurídica contemplada en su conjunto (...) El objeto del contrato será su contenido económico, tal como lo han querido las partes ${ }^{37}$.

34 Ferri, Luigi, "Lecciones sobre el contrato". En: Curso de Derecho Civil, presentación, notas y edición a cargo de Rómulo Morales Hervias y Leysser L. León, trad. de Nélvar Carreteros Torres, $1^{a}$ edición, Editora Jurídica Grijley, Lima, 2004, pp. xliv-xlvi.

Larroumet, Christian., Teoría general del contrato, volumen I, trad. Guerrero, Jorge, Editorial Temis S.A., Bogotá, 1999, pp. 286-289.

36 Código Civil francés. Téngase presente que el Código Civil peruano sí hace la diferencia.

37 Entendemos que ese contenido económico no radica sino en el propósito para fines del tráfico o intercambio económico de bienes y servicios, lo cual se alcanza mediante la respectiva relación jurídica de contenido obligacional, que permite poder exigir cierta conducta, en el marco de la relatividad, para satisfacer los intereses económicos comprometidos. 
Pero el problema consiste en saber cuál es la utilidad de la noción de objeto del contrato, considerada independientemente del objeto de determinada obligación originada por el contrato. Se pretende que se trata de someter el contrato al control del juez, quien verificará si la operación está conforme con el orden público y con las buenas costumbres ${ }^{38}(\ldots)$

No obstante, recurrir a la noción de objeto del contrato es inútil, porque el control del juez, en cuanto a la conformidad del contrato con el orden público y con las buenas costumbres, se ejercerá, sea por la vía del objeto de la obligación creada por el contrato, sea mediante la noción de causa ${ }^{39}$.

\section{$(\ldots)$}

[L]a idea del fin perseguido, que supone que se busquen las razones del acuerdo de voluntades, es ajena al objeto, mientras que realmente constituye el meollo de la noción de causa del contrato. La causa del contrato permite al juez ejercer un control sobre la moralidad del contrato y sobre su licitud por la vía del fin perseguido, sin que haya lugar a tener en cuenta el objeto de las obligaciones creadas. Este objeto puede ser perfectamente neutral $y$, por consiguiente, válido, lo cual no impedirá considerar al contrato como ilícito o inmoral en función del fin que debe alcanzar por el acuerdo de voluntades.

En resumidas cuentas, el objeto del contrato puede aparecer como una complicación inútil. Es el objeto de la obligación lo que es oportuno considerar $^{40 \prime \prime}$.

38 La referida adecuación es para fines de evitar la generación del objeto ilícito (contravención de normas imperativas), prohibido (contravención del orden público) e inmoral (contravención de las buenas costumbres), esto es, en general de lo que podemos denominar objeto antijurídico o en contravención al ordenamiento.

La noción de causa subjetiva es distinta a la de causa objetiva; el tema motivacional es independiente al propósito negocial relevante, digno de tutela y protección para el ordenamiento jurídico, en función mediata al interés social comprometido.

40 Estimamos que no hay tal complicación, y que sí se justifica la noción de objeto contractual. Si asumimos que el contrato tiene como propósito la creación consensuada de una determinada relación jurídica, perfeccionado constitutivamente sólo subsiste esa relación jurídica. Eso es lo que pretenden las partes. Otro tema es que la relación jurídica obligacional constituida pretende obtener la ejecución de una prestación o conducta debida, para alcanzar finalmente un bien o servicio, una "cosa" en sentido general. Lo más cómodo es identificar los requisitos de la prestación, y de la cosa misma, pero ello no significa obviar que ellos representan el interés mediato de las partes, el efecto o consecuencia que se desprende de haberse configurado la relación jurídica sin la cual no sería posible exigir lo debido. En otras palabras, si bien el objeto contractual puede parecer de contenido abstracto, al igual que su característica que es la licitud o adecuación al ordenamiento, no por ello deja de ser un concepto necesario para poder alcanzar el propósito mediato o concreto de las partes, que a través de la conducta debida se tenga acceso al bien o servicio comprometido. 
11. En síntesis, para fines del tráfico o intercambio de bienes y servicios, las partes contratan; con ello sólo instituyen relaciones jurídicas específicas, obligacionales, sujetas al principio de relatividad (los efectos directos que se desprenden de ellas sólo comprometen a las partes centros de interés afectados por su celebración, no a terceros). Creada la obligación (interés abstracto del acreedor), el contrato alcanzó su finalidad existencial $y$, en consecuencia, se extingue. Es en función al vínculo generado, que puede exigirse la conducta debida, lo cual permitirá satisfacer el interés concreto del acreedor.

Por ello, puede sostenerse que el objeto contractual inmediato o abstracto es la obligación, siendo que la prestación sobre la cual versa está orientada a lograr la consecución de la "cosa" que es el objeto mediato o concreto, porque si bien uno puede teorizar sobre qué es lo que se proponen las partes al contratar, no puede obviarse que más allá de la explicación académica, en el entendimiento ordinario lo que se pretende es obtener un bien o servicio.

\section{Sobre la transferencia convencional de propiedad}

1. Uno de los temas más controvertidos que tenemos probablemente en nuestro medio en materia de contratos y derechos reales es lo relativo a cuándo se entiende transferida la propiedad inmobiliaria cierta sobre la base que se ha celebrado un contrato de cambio, por ejemplo, a título de compraventa ${ }^{41}$. Si bien la propiedad, como derecho real por excelencia ${ }^{42}$, se puede adquirir de diversas maneras (apropiación, accesión, usucapión, etc., esto es, a través de lo que se denomina modos originarios y derivados ${ }^{43}$ ), para fines de este trabajo nos interesa una en particular: la transferencia derivada, convencional o proveniente de un acuerdo de voluntades entre el transferente y el adquirente.

El artículo 949 del Código Civil de 1984 establece lo siguiente: "La sola obligación de enajenar un inmueble determinado hace al acreedor propietario de él, salvo disposición legal diferente o pacto en contrario".

41 Nos remitimos a lo expresado en su momento en "Compraventa y transferencia de propiedad inmueble", trabajo publicado generosamente en Advocatus Nueva Época, revista de los alumnos de la Facultad de Derecho y Ciencias Políticas de la Universidad de Lima, n³, Lima, 2000, pp. 29-39. Si bien reafirmamos gran parte del análisis realizado en su oportunidad y de las conclusiones propuestas, estimamos que dicho trabajo requiere complementarse con el presente, atendiendo a que en este último hay conceptos que son expuestos de manera más puntual y precisa.

42 Avendaño Valdez, Jorge, "La propiedad en el Código civil". En: Estudios sobre la propiedad, Giovanni F. Priori Posada (ed.), $1^{\text {a }}$ edición, Fondo Editorial de la Pontificia Universidad Católica del Perú, Lima, 2012, pp. 111-121.

43 González Linares, Nerio. Derecho Civil Patrimonial. Derechos Reales, $1^{\text {a }}$ edición, Palestra Editores, Lima, 2007, pp. 309-311. 
2. Si por contratos de cambio entendemos a aquellos que están orientados a generar una transferencia de propiedad, el Código Civil de 1984 regula a las siguientes modalidades: compraventa, permuta, suministro y donación. Si bien el contrato de mutuo implica formalmente una transferencia de propiedad, la misma no es típicamente tal ${ }^{44}$, porque siendo una operación de préstamo, no existe una adquisición con vocación de perpetuidad, debiéndose tener presente que por la naturaleza del bien comprometido (fungible y consumible), uso se identifica finalmente con consumo ${ }^{45}$. Tratándose del suministro, dejamos a salvo que el mismo, en función a la naturaleza del bien sobre el cual recae, y al interés de las partes, puede ser inclusive en uso. En todo caso, dejamos constancia que, tratándose de la materia controvertida sobre la transferencia convencional inmobiliaria, adquieren singular relevancia los contratos de compraventa, permuta y donación, por lo que dejamos de lado al suministro y al mutuo, dado que estos contratos se asocian al tráfico mobiliario. Sabemos bien que no se trata de los únicos contratos de cambio, ya que la transferencia inmobiliaria también puede verificarse bajo otros títulos, tales como una dación en pago (que se le apliquen las reglas de una compraventa no significa que sea tal), la transacción, etc.; empero, destacamos los señalados contratos de compraventa, permuta y donación en función a que poseen una tipicidad legislativa que se enfoca en el carácter obligacional.

3. Con relación a su eficacia tratándose de la transferencia de derechos reales, es admitido que los contratos pueden ser obligacionales o traslativos ${ }^{46}$. Tratándose de los primeros, la celebración del contrato implica la asunción de una obligación que demanda en el deudor la ejecución de la prestación (conducta debida) de transferir la propiedad a favor del acreedor; en cambio, en el caso de los segundos, la celebración misma del contrato conlleva a que, por esa sola circunstancia, el adquirente se haga de la propiedad, no hay asunción obligacional, menos corresponde hacer referencia a una ejecución prestacional a cargo del deudor. Adviértase que, en el caso de los contratos con efectos reales, no estamos haciendo mención al acreedor de la transferencia, ni al

44 Sobre este particular, tomando las clasificaciones contractuales que propone el profesor Messineo, bien podríamos conceptualizar que el mutuo es un contrato de disponibilidad y restitución, atendiendo que en función a la naturaleza del bien se adquiere finalmente un derecho particularmente intenso que no encuadra con la propiedad, siendo que a la finalización de la duración de la relación jurídica generada, debe restituirse dicho bien (más bien, devolverse, por la falta de identidad singular) en la misma especie (agregaríamos cantidad y calidad) o su equivalente. Messineo, Francesco. Doctrina General del Contrato, tomo I, trad. R.O. Fontanarrosa, S. Sentís Melendo y M. Volterra, Ediciones Jurídicas Europa-América, Buenos Aires, 1986, p. 427.

45 Díez-Picazo, Luis y Gullón, Antonio. Sistema de Derecho Civil, volumen II, tomo 2 Contratos en especial. Cuasi contratos. Enriquecimiento sin causa. Responsabilidad extracontractual, 10ª edición, Editorial Tecnos (Grupo Anaya S.A.), Madrid, 2012, p. 169. edición, trad. Ariano Deho, Eugenia, Gaceta Jurídica, Lima, 2009, pp. 477-479. 
deudor de la misma, dado que no se está ante contenidos obligacionales. Además, adviértase que en función al régimen de objeto contractual al cual nos adscribimos (por letra y espíritu de la ley), cabe cuestionarse si el respectivo acuerdo es un contrato o no.

El tema radica en que al contrastar la redacción de los artículos que tipifican a los contratos de cambio señalados anteriormente con lo establecido en los artículos $947^{47}$ y $949^{48}$ del Código Civil, estaríamos frente a una nueva incongruencia textual, frente a lo cual tenemos la posibilidad de destacarla como si fuese una contradicción inocultable del legislador, o postular una lectura e interpretación que salve al aparente conflicto, concluyendo que no hay desfase entre las normas de fuentes de las obligaciones y las de derechos reales.

Sobre la base de lo sancionado en las disposiciones generales sobre contratación (artículos 1351 y 1402 del Código Civil de 1984, principalmente), los tipos negociales de los contratos de compraventa, permuta y donación (e inclusive los de suministro y mutuo) son consistentes con la noción del objeto de carácter obligacional.

Así, los artículos 1529, 1602 y 1621 del Código Civil establecen, respectivamente lo siguiente: "Por la compraventa el vendedor se obliga a transferir la propiedad de un bien al comprador y éste a pagar su precio en dinero; (...) Por la permuta los permutantes se obligan a transferirse recíprocamente la propiedad de bienes; (...) Por la donación el donante se obliga a transferir gratuitamente al donatario la propiedad de un bien". (Subrayado agregado).

De otro lado, tratándose del contrato de suministro, el artículo 1604 del Código Civil sanciona su carácter obligacional, que si bien no hace mención expresa a que el suministrante se obliga a entregar en propiedad, periódica o continuadamente, bienes a favor del suministrado, ello se colige sistemáticamente del artículo 1609 del mismo cuerpo normativo. Y en el caso del contrato de mutuo, si bien el artículo 1648 del Código Civil también sanciona (como no podía ser de otra manera) su carácter obligacional, en lo que se refiere a la obligación de transferir la propiedad se está a lo dispuesto en su artículo 1654, en el sentido que la obligación de entregar es para fines de transferir la respectiva propiedad.

47 "La transferencia de propiedad de una cosa mueble determinada se efectúa con la tradición a su acreedor, salvo disposición legal diferente".

48 "La sola obligación de enajenar un inmueble determinado hace al acreedor propietario de él, salvo disposición legal diferente o pacto en contrario". 
En otras palabras, tratándose de los contratos de cambio recogidos en nuestra legislación civil, no cabe duda que son obligacionales en función a su respectivo tipo o descripción (y regulación) normativa ${ }^{49}$.

Y en el escenario de admitirse un contrato atípico, es más, innominado, de cambio, estimamos que en razón de lo sancionado en el artículo 1353 del Código Civil ${ }^{50}$, debería también admitirse que se replica el efecto obligacional, atendiendo a los alcances de sus artículos 1351 y 1402. Cosa distinta será si las partes acuerdan un negocio patrimonial pero sin contenido obligacional, caso excepcional donde podría admitirse la generación de efectos reales.

Conforme a lo anterior, siendo que la celebración del contrato implica la formación de una relación obligacional, luego de lo cual el contrato se extingue al haber logrado su cometido, subsistiendo la relación jurídica instituida, resulta manifiesto que lo que será materia de ejecución será la actividad del deudor, positiva o negativa: la prestación. En tal virtud, si el contrato celebrado fue uno de cambio y se asumió el compromiso obligacional de transferir propiedad, lo que debe ejecutarse para fines de esa transferencia es una conducta debida, lo cual se relaciona a la noción de los modos o maneras de exteriorizar la transferencia de propiedad ${ }^{51}$, aceptándose respecto a ellos que son la tradición (o entrega del bien) y la inscripción registral (aunque ésta no excluye, ni tiene por qué excluir a la tradición). Dado que el sistema registral no es constitutivo en nuestro ordenamiento legal (como regla general, dejándose a salvo lo relativo a la hipoteca), no podemos sino concluir que la prestación a cargo del transferente para cumplir con su compromiso obligacional de transferir propiedad sería la entrega del bien mismo ${ }^{52}$, más allá que dicha entrega se realice por cualquiera de las maneras consideradas en los artículos 901 (tradición real o material), 902 (tradición sucedánea) y 903 (tradición ficta o documental) del Código Civil, entrega que en todo

49 Entendemos por tipo a un determinado modelo de operación económica que no sólo es relevante para el ordenamiento jurídico, sino que inclusive ingresa al plano legislativo (el tipo legal frente al que es simplemente social), la utilidad del "tipo" radica fundamentalmente en que permite determinar las reglas aplicables al respectivo negocio y, por consiguiente, los derechos y obligaciones de las partes, conforme expresa Roppo (En: El Contrato, $1^{\text {a }}$ edición, trad. Ariano Deho, Eugenia, Gaceta Jurídica, Lima, 2009, pp. 393-394), pudiéndose identificar las reglas imperativas y las de carácter supletorio.

"Todos los contratos de derecho privado, inclusive los innominados, quedan sometidos a las reglas generales contenidas en esta sección, salvo en cuanto resulten incompatibles con las reglas particulares de cada contrato"

51 Destacamos lo relativo a la exteriorización porque se está ante un derecho real que es conceptualmente un poder, por lo que su existencia como titularidad reclama de "otros", de terceros a los cuales oponerse.

52 Transferencia de propiedad, no como un tema con eficacia relativa o sólo entre las partes contratantes, sino efectiva transferencia, con eficacia absoluta, oponible a terceros en general, que le permita al adquirente ser efectivo titular de un "poder". 
caso demandaría complementarse con la inscripción registral, atendiendo a lo que dispone el artículo 2022 del mismo cuerpo legislativo.

4. El problema es que lo expresado precedentemente no coincidiría con lo que se consta textualmente en el artículo 949 del Código Civil, en materia de transferencia de propiedad inmueble cierta.

Nos encontramos nuevamente ante la misma encrucijada presentada respecto al artículo 1351 del Código Civil. Estamos convencidos que resulta necesario "tomar una actitud más positiva e intentar la interpretación de la norma cuestionada (...) para otorgarle su verdadero sentido a través de su relación con las demás en su conjunto ${ }^{53 \prime \prime}$. Lo que no debemos hacer es obviar todo aquello que explica el tenor de la norma, por más imperfecto que sea, limitándonos a analizarla aisladamente, prescindiendo del criterio histórico y sistemático que la informa, presentando nuestras personales y actuales apreciaciones como si fuesen lo que se representó el codificador en el proceso de elaboración del Código Civil que se extendió casi por veinte años desde el año 1965.

De la Puente en el estudio "La teoría del título y el modo" contenido en su obra "Estudios sobre el contrato de compraventa"54 cuida de explicar detalladamente por qué estima que el artículo 949 del Código Civil corresponde a una norma que resulta ajena, postiza, al sistema legal peruano, pero sin que ello signifique postular que en materia de transferencia de propiedad inmueble nos adscribimos al sistema espiritualizado o del "solo consensus". Este juicio es fundamental. No estamos ante un sistema espiritualizado en que la propiedad de transmite por la sola voluntad o "solo consensus" (sistema de la unidad del contrato bajo la modalidad del principio contractual puro) sino que nos adscribimos tanto en materia de bienes muebles como inmuebles a un sistema de transferencia obligacional (sistema de la unidad del contrato pero bajo la modalidad de la yuxtaposición de los principios de unidad y de la tradición, esto es, la teoría del título y modo).

En efecto, destaca Manuel De la Puente que en el proceso de elaboración del Código Civil, la "Comisión Reformadora", en el libro de derechos reales, clasificó a los bienes en registrados y en no registrados, siendo que en lo concerniente a su transferencia convencional, tratándose de los bienes registrados (más allá que fuesen muebles o inmuebles) sería necesaria la inscripción registral, mientras que tratándose de los no registrados, el medio de transferencia sería mediante la entrega o tradición. Resultaba manifiesto que, de manera concordante con lo previsto en el libro de fuentes de las

53 De la Puente y Lavalle, Manuel, El contrato en general. Comentarios a la Sección Primera del Libro VII del Código Civil, Tomo II, tercera reimpresión de la segunda edición actualizada, Palestra Editores, Lima, 2011, p. 667.

54 De la Puente y Lavalle, Manuel. Estudios sobre el contrato de compraventa, primera edición, Gaceta Jurídica Editores S.R.L., Lima, 1999. 
obligaciones, el codificador se adscribía a una visión obligacionista de los contratos, a lo que se identifica como la "teoría del título y modo". El problema radica en que la "Comisión Revisora" no compartió el criterio de clasificación de los bienes atendiendo a su situación registral ${ }^{55}$, por lo que optó por mantener la secular clasificación de bienes muebles e inmuebles. Atendiendo a ello, y siempre sobre la base que el contrato (título del cual se deriva la transferencia) era obligacional, el codificador a nivel de la "Comisión Revisora" replanteó la manera de transferir convencionalmente la propiedad. Prosigue explicando el maestro que el legislador pudo haberlo hecho señalando que, en cualquier caso se requiere la entrega, más allá de la posibilidad de inscripción registral para alcanzar un derecho consolidado plenamente, pero no. El legislador nacional va a establecer que tratándose de los bienes muebles, como regla general, se transfieren por la entrega o tradición; mientras que para los bienes inmuebles, como regla general, no se requiere de su entrega, siendo suficiente la sola obligación de enajenarlos, ya que la asunción de dicha obligación hace propietario al acreedor. Adviértase que los artículos 947 y 949 del Código Civil en ambos casos hacen mención al acreedor, y por ende, de manera implícita al deudor, de manera que se emplea un lenguaje de contenido "obligacional".

Desde el preciso instante en que el legislador define que en materia mobiliaria es necesaria -como regla general- la tradición, resulta manifiesto que se representa que la transferencia se adscribe a la teoría del título y modo, donde el contrato es el título (causa) y la entrega el modo (efecto). Sin embargo, cuando el legislador define que en materia inmobiliaria es suficiente -como regla general- la sola asunción de la obligación de enajenar, sin que sea aparentemente necesaria tradición alguna, se genera el problema interpretativo: ¿la sola celebración del contrato de cambio inmobiliario transfiere propiedad al acreedor? Si la respuesta es afirmativa, debe concluirse que ya no se estaría entonces ante contratos obligacionales sino traslativos. Si la respuesta es negativa, ¿cómo explicar la redacción del artículo 949 del Código Civil peruano que sugiere cosa distinta?

"La actual redacción del artículo 949 del Código Civil ha dado lugar a que la doctrina peruana se encuentre dividida en dos sectores: uno de ellos opina que el sistema peruano de adquisición de la propiedad está articulado en la aplicación de la teoría del título y el modo para el caso de los bienes muebles y la aplicación del principio de la transmisión solo consensu para el caso de los bienes inmuebles; el otro sector sostiene que tanto para el caso de los bienes muebles como para el de los bienes inmuebles debe aplicarse la teoría del título y el modo" ${ }^{56}$.

55 No puede obviarse una realidad: a inicios de los años ochenta, el sistema registral peruano era más que deficiente, con limitada presencia y desarrollo a nivel nacional.

56 De la Puente y Lavalle, Manuel. Estudios sobre el contrato de compraventa, $1^{a}$ edición, Gaceta Jurídica Editores S.R.L., Lima, 1999, p. 23. 
5. Corresponde analizar lo que explicaría el sentido del artículo 949 del Código Civil.

Esta última disposición habría sido tomada (en el contexto del cambio de criterio de la clasificación legal de los bienes de la "Comisión Reformadora" a la "Comisión Revisora") de lo que ya figuraba en el artículo 1172 del Código Civil de 1936 "(...) olvidando que ella estaba contenida en el Libro del Derecho de Obligaciones y no en el Libro de Derechos Reales ${ }^{57 "}$.

No hay duda de ello si se contrastan los correspondientes artículos.

Artículo 1172 del Código Civil de 1936: "La sola obligación de dar una cosa inmueble determinada, hace al acreedor propietario de ella, salvo pacto en contrario".

Artículo 949 del Código Civil de 1984: "La sola obligación de enajenar un inmueble determinado hace al acreedor propietario de él, salvo disposición legal diferente o pacto en contrario".

En otras palabras, siguiendo la explicación que proporciona Manuel de la Puente, si bien fue replanteada la clasificación legal de los bienes, no se abandonó la "teoría del título y modo", por lo que no hubo cambio alguno de criterio sobre la manera de transferir la propiedad, partiéndose de la premisa del contrato con efectos obligacionales y no reales.

El ilustre maestro rechaza, en consecuencia, la posibilidad de admitir un sistema espiritualizado (al menos en materia de transferencia de propiedad inmueble, dado lo incontrastable del artículo 947 del Código Civil en el ámbito mobiliario), tesis que fue invocada por el profesor Forno ${ }^{58}$ al analizar el régimen de transferencia de bienes que sería aplicable en nuestro país. En efecto, este último jurista sostiene, partiendo de las nociones dogmáticas de lo que es una relación obligacional, que ésta supone necesariamente una conducta debida, una actuación positiva o negativa del deudor, lo cual consiste en la prestación; desde dicho punto de vista, cuestiona que se pueda sostener que los contratos de cambio inmobiliarios son obligacionales, siendo que ello no sería más que una argumentación vacía y formalista, dado que el deudor (transferente) no tiene que ejecutar prestación alguna ya que la transferencia se produce por mandato legal, proviene del propio contrato, al margen de la actuación del deudor. Por consiguiente, estima el profesor Forno que, en el fondo, -se lo haya representado o no el codificador- lo cierto es que el respectivo contrato posee efectos reales. Puede apreciarse que se trata de una tesis bastante puntual, comprensible

57 De la Puente y Lavalle, Manuel. "El contrato con efectos reales". En: Ius et Veritas, revista editada por estudiantes de la Facultad de Derecho de la Pontificia Universidad Católica del Perú, nº 9, Lima, 1994, p. 14.

58 Nos remitimos al respectivo trabajo del profesor Forno, Hugo: "El contrato con efectos reales". En: Ius et Veritas, revista editada por estudiantes de la Facultad de Derecho de la Pontificia Universidad Católica del Perú, n 7, Lima, 1993, pp. 77-87. 
fácilmente, y que ha atraído y atrae a muchos estudiantes de derecho y abogados; es más, el propio De la Puente destaca al expresar: "La argumentación es muy ingeniosa y pone en relieve la flexibilidad del Derecho para acomodarse a planteamientos diversos, siempre, desde luego, que descanse en razonamientos lógicos y bien estructurados, como es el caso ${ }^{59 \prime \prime}$.

Escapa a los fines del presente trabajo realizar una presentación de los argumentos presentados por diversos juristas nacionales sobre los alcances del artículo 949 del Código Civil ${ }^{60}$. Pero queda clara al menos una cosa, y es que el lenguaje empleado en su redacción puede interpretarse según las convicciones del lector, lo cual resulta preocupante porque estamos frente a una regla fundamental en el ámbito del derecho civil patrimonial. Conforme ya hemos expresado, el lenguaje legislativo debe ser uno comprensible, ello implica redacción clara y simple, evitándose interpretaciones variadas y que generan desconcierto, más aun cuando se carece de criterios judiciales estandarizados sobre ciertas materias. En tal virtud, insistimos en lo que ha sido propósito declarado de este trabajo: la norma no puede ser analizada sólo desde un plano textual, sino de manera histórica y sistemática, para que la interpretación que se proponga sea la más fiel a lo que el codificador se representó en su momento, al margen que coincidamos o no con dicha representación. Sin perjuicio de ello, este ejercicio de interpretación debe también llevarnos a una reflexión sobre la responsabilidad a la cual está sujeto todo legislador y sobre la necesidad de introducir precisiones (consistentes orgánicamente) en el articulado del Código Civil.

6. La discrepancia sobre la naturaleza jurídica del contrato de cambio inmobiliario ha generado y genera diversas opiniones jurídicas. De ellas nos interesa referirnos a la posición adoptada por los profesores Felipe Osterling y Mario Castillo, lo cual tiene especial significado porque el primero de ellos presidió y fue miembro de la "Comisión Reformadora", por lo que sus explicaciones nos permiten apreciar cuál fue el entendimiento del legislador en ciertas materias cruciales.

Como corresponde, Osterling y Castillo ${ }^{61}$ van a remontarse a verificar cómo se reguló la transferencia convencional de propiedad en el primer código civil del país, destacando que el Código Civil peruano de 1852 seguía al modelo francés, en el sentido que la transferencia mueble o inmueble se producía de manera automática "al momento del

59 De la Puente y Lavalle, Manuel, Estudios sobre el contrato de compraventa, $1^{\text {a }}$ edición, Gaceta Jurídica Editores S.R.L., Lima, 1999, p. 23.

60 Reiteramos nuestra referencia a un anterior trabajo: "Compraventa y transferencia de propiedad inmueble", publicado generosamente en Advocatus Nueva Época, revista de los alumnos de la Facultad de Derecho y Ciencias Políticas de la Universidad de Lima, n³, Lima, 2000, pp. 29-39.

61 Osterling Parodi, Felipe y Castillo Freyre, Mario, "La transferencia de propiedad en el Perú" En: Ius et Praxis, revista de la Facultad de Derecho de la Universidad de Lima, n 30, Lima, 1999 
nacimiento de la obligación de enajenar, surgida de su celebración ${ }^{62 ",}$ aunque destacando que se trataba de una fidelidad al modelo originario del Code, dado que no se consideró su ley modificatoria del 23 de marzo de 1855 que establecía la necesidad de inscripción registral para la validez (como sinónimo de eficacia) de la transferencia frente a terceras personas ${ }^{63}$. Y luego de ello, ambos juristas van a analizar el proceso de elaboración del Código Civil de 1936, destacando las expresiones de Manuel Augusto Olaechea (responsable final del Libro Quinto "Del derecho de obligaciones" del señalado cuerpo normativo) contenidas en la respectiva exposición de motivos, conforme a las cuales resulta clarísimo que el legislador de 1936 no se representó que la transferencia de propiedad inmueble estuviese adscrita a un sistema traslativo sino obligacional. Por su pertinencia para fines del presente trabajo, y dado que el legislador de 1984 -para fines de la redacción del artículo 949- tomó la regla contenida en el artículo 1171 del Código Civil de 1936, resulta necesario recordar las palabras de Olaechea ${ }^{64}$ :

"Según el Código francés, la propiedad de los inmuebles se trasmite como efecto de la estipulación. Conforme a este sistema, la obligación de entregar se reputa mentalmente ejecutada. La tradición que viene después del pacto, es un hecho que no tiene la virtud de transferir el dominio, sino únicamente de poner al adquirente en aptitud de servirse de la cosa. La obligación nace y muere sin solución de continuidad. Se considera perfecta y ejecutada en el mismo momento de su formación. (...) la tradición no necesita ser real, porque el consentimiento lleva en sí una tradición fingida que produce el mismo efecto; y esta tradición realiza el desplazamiento automático del dominio. El sistema del Código francés fue adoptado por el peruano (se entiende el Código de 1852). El Código Napoleón presume que existe, por decirlo así, una tradición de derecho implícita, y como consecuencia de sistema tan espiritualista, la convención pone los riesgos de la cosa a cargo del acreedor convertido en propietario por el consentimiento.

62 Osterling Parodi, Felipe y Castillo Freyre, Mario, "La transferencia de propiedad en el Perú" En: Ius et Praxis, revista de la Facultad de Derecho de la Universidad de Lima, $\mathrm{n}^{\circ}$ 30, Lima, 1999, p. 150. Aunque los señalados autores sólo se remiten al artículo 1308 del Código Civil de 1852 ("En la venta simple pasa la propiedad de la cosa al comprador, aun antes de su entrega y pago del precio"), estimamos que la referencia legislativa puede complementarse con los artículos 571 ("Por la enajenación se transfiere a otro el dominio de una cosa, o a título gratuito, como en la donación, o a título oneroso, como en la venta y la permuta") y 574 ("La enajenación se completa por la tradición, que es la entrega que se hace de una cosa poniéndola á disposición del nuevo dueño") del señalado código.

Lo cual entendemos que se trata de un tema fundamental en materia de propiedad, porque se trata de un "poder", no de un simple "derecho" con vocación relativa.

64 Osterling Parodi, Felipe y Castillo Freyre, Mario, "La transferencia de propiedad en el Perú" En: Ius et Praxis, revista de la Facultad de Derecho de la Universidad de Lima, ${ }^{\circ}$ 30, Lima, 1999, pp. 152-153. 
El sistema instaurado por el Código francés no ha sido uniformemente seguido por las codificaciones posteriores. La institución creada por aquel Código fue modificada en Francia por la ley del 23 de marzo de 1855, conforme a la cual no se puede oponer a tercero ningún derecho real que no esté previamente inscrito.

El sistema que considera adquirido el derecho real como efecto de la inscripción, mira al interés general y al desarrollo del crédito territorial.

El sistema de la tradición reviste una marcada inferioridad respecto al sistema francés ${ }^{65}$. La tradición es un hecho que no está subordinado a formas especiales; se prueba como todo hecho; y desde el punto de vista de la publicidad es claramente ineficaz.

\section{(...)}

[L]a propiedad de las cosas muebles se adquiere por la tradición, y el dominio de los inmuebles, por el contrato, con las restricciones derivadas de la institución del Registro". (Subrayado agregado).

Sobre la base de ello, Osterling y Castillo van a sustentar que el sistema peruano ha sido fiel al francés, en el sentido, que para fines de transferir propiedad inmueble cierta resultaría suficiente la sola obligación de enajenar, siendo necesaria la inscripción para fines de oposición del derecho a terceras personas (esto último, mediante ley de 1888 que instituye en nuestro medio al Registro de la Propiedad Inmueble), siendo que ello fue recogido, entre otros, en los artículos 1172 y 1050 del Código Civil de 1936.

Concluyen los indicados juristas en que el Código Civil de 1984 no ha modificado dicho régimen:

"(...) consideramos que existe perfecta armonía entre lo dispuesto en el artículo 1529 del Código Civil peruano de 1984 (relativo a la definición del contrato de compraventa), en el sentido que se trata de un acto meramente obligacional, y no traslativo de ningún derecho real, y el artículo 949 del mismo cuerpo legal, referente a la manera como se trasmite la propiedad.

La respuesta al tema de la transferencia de la propiedad inmueble en el Perú no la podemos hallar dentro de principios ajenos a los que históricamente han regido nuestro derecho civil.

\section{(...)}

Consideramos que si bien es cierto que el título está representado por el contrato de compraventa celebrado, no será éste el que transfiera la

65 Entendemos que Olaechea se refiere al sistema de la entrega real o física, ya que postula que en materia de contratos de cambio la sola obligación deriva en la transferencia de propiedad, siendo que ello significa una tradición fingida (ficticia) o que opera por disposición legal (sin necesidad inmediata de actuación por parte del deudor). 
propiedad del bien inmueble, sino la obligación objeto del contrato, cuya ejecución es inevitable -por mandato de la ley-, siempre y cuando estemos en presencia de un bien de propiedad del vendedor, cierto y presente, y no exista disposición legal diferente ni pacto en contrario.

\section{(...)}

Por nuestra parte, podemos afirmar que no existe contradicción alguna entre el artículo 1529 del Código Civil, que establece que el vendedor se obliga a transferir la propiedad del bien al comprador, y el artículo 949, a través del cual se expresa que la sola obligación de enajenar un bien inmueble determinado hace al acreedor propietario de él, salvo disposición legal diferente o pacto en contrario. La primera de las normas es propia del derecho de los contratos (vale decir, de las relaciones obligatorias), en tanto que la segunda es propia de los derechos reales. Lo que ocurre es que técnicamente el contrato genera obligaciones. En este caso el contrato genera la obligación de transferir la propiedad, obligación que nace del contrato y que no debe confundirse con él, obligación que la ley da por ejecutada, como rezago de los dispositivos que al respecto contenía el Código Napoleón y teniendo como fundamento el que expresamos al analizarlos.

\section{(...)}

Así, la obligación de transferir la propiedad inmueble no deja de tener una prestación. (...) Pero, en el caso de la obligación de transferir la propiedad inmueble -por los antecedentes históricos expresados- esta obligación es la única que la ley no permite incumplir a los particulares que contraten en tal sentido. Así, es cierto que la obligación se entiende cumplida con la ejecución de la prestación debida, pero estamos ante un supuesto excepcional en el cual la prestación la ejecuta la propia ley. Es así que en este caso, para la ejecución de la prestación debida no se requiere de ninguna conducta del deudor ${ }^{66 "}$. (Subrayado agregado).

Atendiendo a lo expuesto, no es que la sola celebración del contrato implique la transferencia de propiedad (o que esta última se produzca por el mérito del propio contrato, al generarse el consentimiento formativo), sino que, sobre la base que el contrato despliega efectos obligacionales por su sola celebración, el codificador expresa que es la ley la que dispone, de hecho, que se entienda ejecutada la prestación a cargo del deudor en un contrato de cambio, permitiendo que el acreedor adquiera la propiedad, pero no por el consentimiento formativo contractual (tesis de los efectos reales), sino porque dado que el contrato ya se celebró (y extinguió, subsistiendo únicamente la relación jurídica obligacional que es su objeto), se entiende para todo efecto que la prestación se tiene por cumplida o ejecutada. Regla

66 Osterling Parodi, Felipe y Castillo Freyre, Mario, "La transferencia de propiedad en el Perú" En: Ius et Praxis, revista de la Facultad de Derecho de la Universidad de Lima, $\mathrm{n}^{\circ}$ 30, Lima, 1999, pp. 155-160. 
excepcional, es cierto, por no decir extraña, y que la asociamos a una premisa tradicional del derecho civil patrimonial, en el sentido que se protege a la propiedad inmueble antes que a la mueble ("Res mobilis, res vilis"). La ley sustituye a la actuación debida a cargo del deudor para evitar -como expresan los juristas Felipe Osterling y Mario Castillo- un supuesto de incumplimiento, lo cual reiteramos puede resultar lógico si se pretende "proteger" a los derechos sobre inmuebles, evitando que un incumplimiento frustre el interés del acreedor. Así, atendiendo a que se ha generado jurídicamente una obligación de transferir propiedad, como consecuencia de la válida celebración de un contrato de cambio, la ley hace propietario al acreedor.

En esa misma línea de pensamiento e interpretación se encuentra Manuel de la Puente al señalar que no se puede pretender explicar los alcances del artículo 949 del Código Civil como si se estuviese bajo las reglas contractuales del derecho italiano, siendo por ejemplo que en la tipificación del contrato de compraventa en el Codice no se hace mención alguna a la obligación de transferir onerosamente la propiedad, sino que se refiere a la transferencia misma de propiedad, lo cual se explica porque el Codice tiene un régimen espiritualizado de transferencia, de manera que:

"Se comprende que, en estas condiciones, no se requiera la creación de una obligación para que, mediante la ejecución de la respectiva prestación, se realice la conclusión del contrato de compraventa y se produzca el efecto traslativo de su propiedad.

La situación es distinta en el caso del Código Civil peruano. El contrato en general, como categoría abstracta, tiene por objeto crear obligaciones y el contrato de compraventa, en particular, crea la obligación de transferir la propiedad.

No puede concebirse la celebración de un contrato cuyo fruto no sea una obligación. Sería algo contrario a la naturaleza misma del contrato.

Por eso mismo, la función del contrato de compraventa es crear la obligación de transferir la propiedad de un bien y la función del artículo 949 es otorgar a esa obligación, tratándose de bienes inmuebles determinados, el efecto de hacer al comprador propietario del bien.

Es cierto que no es necesario que el vendedor ejecute una prestación, pero ello no significa que la obligación no exista, pues lo que ocurre es que la ley toma a su cargo la ejecución del efecto traslativo buscado por la obligación de transferir la propiedad ${ }^{67 "}$.

Y como la ley se antepone, se superpone, a la ejecución prestacional a cargo del transferente, entendemos que lo que queda pendiente es lo relativo al perfeccionamiento de la transferencia, para que el adquirente sea titular de un efectivo

67 De la Puente y Lavalle, Manuel, Estudios sobre el contrato de compraventa, $1^{a}$ edición, Gaceta Jurídica Editores S.R.L., Lima, 1999, p. 31. 
derecho real según ya ha sido explicado, de manera que pueda oponerlo, sea eficaz plenamente frente a terceros ajenos a la relación, lo cual coincidimos que se realiza mediante la respectiva entrega ${ }^{68}$. Conforme a ello, el transferente, en el marco de la prestación que debe ejecutar en cumplimiento de su deuda, debe perfeccionar complementariamente, entregando el bien para que el adquirente cuente con un efectivo derecho real, lo cual corresponde a lo establecido en el artículo 1549 del Código $\mathrm{Civil}^{69}$ en materia de compraventa (con la precisión que el concepto regulado en dicho artículo es igualmente aplicable a todos los contratos de cambio, porque se trata que la propiedad relativa ("inter partes") derivada del contrato, o para ser más rigurosos, de la relación jurídica obligacional, pase a ser una absoluta ("erga omnes"), una propiedad plena).

En otras palabras, consistentemente con el régimen obligacional propio de todo contrato, y atendiendo a los alcances ya comentados del artículo 949 del Código Civil, su artículo 1549 va a regular el tránsito de la propiedad de un "derecho" a un "poder", ya que la propiedad conlleva consustancialmente la oponibilidad, la posibilidad de exclusión.

\section{A modo de conclusión}

Más allá de haber pretendido exponer en función a qué corresponde interpretar las reglas del Código Civil en materia de objeto contractual y transferencia convencional de propiedad inmueble, creemos que no puede negarse que la redacción del Código Civil de 1984 no es precisamente la más feliz e invita a varias lecturas. Y desde el momento en que hay una pluralidad de posibles interpretaciones pueden generarse pronunciamientos judiciales disímiles por completo, y eso quiebra toda predictibilidad y seguridad jurídica. Ahí radica la trascendencia del tema.

Y desde la posición que hemos adoptado sobre el régimen de transferencia de propiedad inmobiliaria en nuestro sistema legal, no puede tampoco negarse que una pretendida transferencia sin actuación del deudor, sin ejecución prestacional por relevamiento de la ley, postulándose que es una adquisición directa proveniente de la relación obligacional y no del contrato mismo, puede presentar sutilezas que ceden ante explicaciones más directas y sencillas, aunque ajenas al sentir del legislador y a nuestra tradición misma. Estimamos que resulta válido recurrir a las sutilezas en ciertas

68 De la Puente y Lavalle, Manuel, Estudios sobre el contrato de compraventa, $1^{\text {a }}$ edición, Gaceta Jurídica Editores S.R.L., Lima, 1999, pp. 119-130. Nos remitimos nuevamente a un anterior trabajo: "Compraventa y transferencia de propiedad inmueble". En: Advocatus Nueva Época, revista de los alumnos de la Facultad de Derecho y Ciencias Políticas de la Universidad de Lima, n³ , Lima, 2000, pp. 29-39, en donde se desarrolla con mayor detalle estos alcances del perfeccionamiento complementario, desde la óptica del autor.

69 "Es obligación esencial del vendedor perfeccionar la transferencia de propiedad del bien". 
circunstancias, dependiendo siempre de las personas a las cuales nos dirigimos, pero también estimamos que no es precisamente lo más idóneo para un texto legal que debería ser fácilmente comprensible y aplicado por igual en todo el territorio nacional, máxime cuando estamos nada menos que frente a la normatividad fundamental en el ámbito del derecho privado.

En la elaboración del Código Civil de 1984, y en los propios antecedentes de este último, inclusive en el Código Civil de 1936, hubo una determinada opción legislativa y creemos que está allí la clave del asunto para interpretar adecuadamente las "sutilezas" referidas anteriormente: artículo 1402 del Código Civil, conforme al cual se define que los contratos son obligacionales. En consecuencia, no puede sustentarse legislativamente una eficacia real, y menos puede sostenerse que los codificadores de derechos reales y de obligaciones y contratos tuvieron lecturas contrapuestas. El entendimiento fue el mismo: el contrato es obligacional, y para transferirse propiedad (en el marco de una relación obligacional generada por un contrato), como derecho real, se requiere siempre de un modo o comportamiento.

Sin embargo, retomando lo ya manifestado sobre el lenguaje legislativo, resulta seguramente conveniente una adecuación de textos, pero considerando siempre un elemental criterio de sistematicidad, ya que la transferencia de propiedad derivada parte de la premisa que hay un contrato, siendo que el legislador se preocupó expresamente en definir al objeto contractual para evitar discusiones e interpretaciones disímiles.

En síntesis, postulamos que en esta materia no sea probablemente suficiente "(...) tomar una actitud más positiva e intentar la interpretación de la norma cuestionada utilizando especialmente los medios o elementos lógico y sistemático, para otorgarle su verdadero sentido a través de su relación con las demás en su conjunto", sino que por la trascendencia económica del tema debería replantearse la redacción del artículo 1351 como del propio artículo 949 del Código Civil en términos tales que no genere dudas sobre sus alcances.

Quizá ya haya llegado el momento de retomar la propuesta de clasificación legal de los bienes en función a su situación registral, y de manera correlativa de cómo entender que se transfieren constitutivamente. 